\title{
Comments on birchbark documents found in the twenty-first century
}

\author{
Замечания к берестяным грамотам, найденным в XXI веке
}

\author{
Jos Schaeken $^{1}$
}

Published online: 24 April 2017

(C) The Author(s) 2017. This article is published with open access at Springerlink.com

\begin{abstract}
This article presents a general overview and highlights some specific features of the birchbark texts that are included in the twelfth volume of the series Novgorodskie gramoty na bereste. This volume offers full critical editions of all texts found in Novgorod and Staraja Russa between 2001 and 2014. My chief goal is to scrutinize systematically the wealth of new information and to show the recent dynamic shifts in the research field. Special attention is paid to the reconstruction and analysis of two large social networks which can be established on the basis of the new data.
\end{abstract}

Аннотация Статья содержит наряду с общим обзором детальный анализ характерных особенностей берестяных грамот, включенных в XII том серии Новгородские грамоты на бересте. Этот том представляет полное критическое издание находок из Новгорода и Старой Руссы, сделанных в период с 2001 по 2014 г. Главная цель автора заключается в систематическом выделении новой информации, которую несут в себе опубликованные тексты, а также в демонстрации динамики современных исследований в этой области. Особое внимание уделяется реконструкции и анализу двух разветвленных социальных сетей, выявленных на основе новых данных.

\section{Introduction}

On Wednesday, 21 July 2010, birchbark document no. 1000 was unearthed in Novgorod, almost exactly fifty-nine years after the discovery of the first birchbark with a text inscribed on it. N1000 (where 'N' stands for Novgorod) contains a short message dating from the midtwelfth century: 'From Kyas and from Žiročko to Tverdjata and to Ivan. We are both fine'. This may look like a postcard saying, 'Having a wonderful time; wish you were here!'. However,

I am greatly indebted to Daniel E. Collins, Simeon Dekker and Sasha Lubotsky for their feedback on earlier drafts. I would also like to thank Alexey A. Gippius and Savva M. Mikheev for providing me with the most recent research data.

\footnotetext{
$\triangle$ J. Schaeken

j.schaeken@hum.leidenuniv.nl

1 Department of Russian and Eurasian Studies, Leiden University, Leiden, The Netherlands
} 
if we compare N1000 with other birchbark finds from 2010 and later (especially 2012), it becomes clear that Kyas, Žiročko, Tverdjata and Ivan were business associates and that the message sent to Novgorod was meant to convey that the authors were fulfilling their mission somewhere outside of town, which is known to their addressees-in other words, that their mutual concerns are prospering. As brief and ephemeral as N1000 may appear at first sight, it turned out to be part of a whole series of birchbark letters, which can be connected to a large network of business partners (see further below, Sect. 4).

The landmark N1000 is included in the twelfth volume of the series Novgorodskie gramoty na bereste $(N G B)$, which comprises the systematic publication of birchbark finds by the Russian Academy of Sciences (Vol. 1, 1953-Vol. 12, 2015). The editors of NGB 12-V. L. Janin, A. A. Zaliznjak and A. A. Gippius ${ }^{1}$ - present full critical editions and drawings of all birchbark finds from Novgorod and near-by Staraja Russa between 2001 and 2014, totaling 146 texts from Novgorod (N916-N959 and N962-N1063) ${ }^{2}$ and nine from Staraja Russa (nos. $37-45$ ). This amounts to an increase of almost $15 \%$ in the corpus of birchbark documents from both locations.

The majority of the birchbarks from Novgorod (108) were found at the Trinity Excavation (Troickij raskop), which is located at the site of the residences of the boyars of Ljudin End, south of the kremlin (Detinec), on the left bank of the Volxov River (Sophia Side). In 2003, one birchbark was unearthed at Gorodišče (N950, also known as 'Gorodišče no. 1'), three kilometers outside of Novgorod, where in the ninth century the residence of the princes of Novgorod was established. ${ }^{3}$

\subsection{Chronological distribution}

Three quarters of the new finds are dated prior the Mongol-Tatar invasion, i.e. in the Early Old Russian period before 1220 . The second half of the twelfth century especially (ca. 11401200 ) is well represented with more than one hundred documents. See Fig. 1, in which the dotted line shows the chronology of the birchbark texts published in NGB $12 .{ }^{4}$ If we compare the distribution in time, we see that it roughly corresponds with the chronological development of previously known texts from the birchbark corpus (see the grayscale line). ${ }^{5}$ The

\footnotetext{
${ }^{1}$ It should be noted that E. V. Toropova, together with Janin and Zaliznjak, co-edited the publication of the texts from Staraja Russa (NGB 12, pp. 166-176).

${ }^{2}$ The small fragments N960 and N961 had already been found by 1992, but were not numbered at that time: (see NGB 12, p. 68). The count of 146 texts also includes the combined numbers N980 and N1029, which were found in different years and turned out to form a single text (labeled '1029/980').

${ }^{3}$ See NGB 12 , pp. 3-9, for a detailed overview of the archeological excavation sites. Note that the map on pp. 8-9 with detailed topographic information on the Trinity-XIII and Trinity-XIV sites shows a couple of inconsistencies: N1000 is registered in kvadrat 1813, whereas on p. 99, where we find the edition of the text, kvadrat 1812 is given as the exact location. Also, N1029 is located in kvadrat 1840 on the map, in contrast with kvadrat 1846 as mentioned on p. 127.

${ }^{4}$ Based on the data provided in NGB 12, pp. 192-193; possible alternative dates given in the edition (one interval earlier or later, indicated by arrows to the left and/or right of the date; cf. NGB 10, p. 145) have been ignored. For chronological distribution, I follow the main principles provided in NGB 10 (ibid.): for the twelfth, thirteenth and fourteenth centuries regular intervals of twenty years are used. Documents from the eleventh century are categorized into three periods of twenty-five years (the earliest one being 1025-1050). In contrast with NGB 10 (ibid.), the first half of the fifteenth century is divided into two intervals (1400-1420, 1420-1450), in order to have a more balanced time scale on the horizontal axis of Fig. 1.

${ }^{5}$ Based on the data provided in NGB 10, pp. 145-151. In addition, the chronological data for the finds from Toržok have been included (ibid., pp. 414-416; NGB 11, pp. 120-137). Note that the chronological analysis in Schaeken (2012a, pp. 209-223) was conducted in a slightly different way (see ibid., pp. 211-212); this, however, does not affect the general picture of the distribution in time.
} 
Fig. 1 Chronological distribution of birchbark documents up to and including 2015

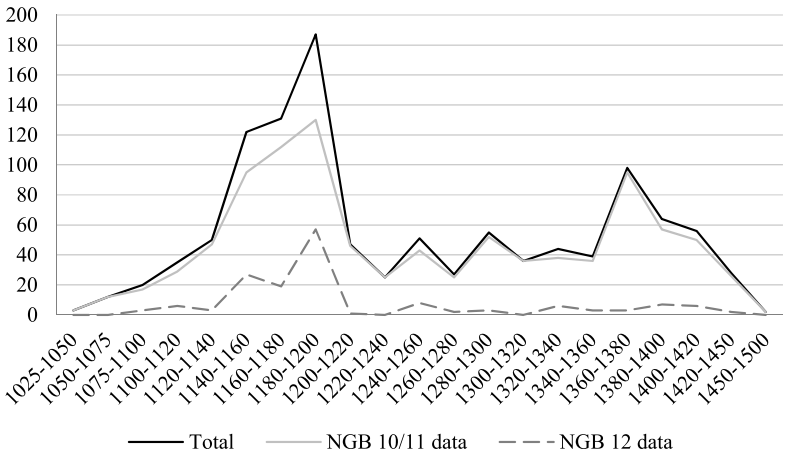

overall distribution (black line) appears to be consistent over the last three decades, ${ }^{6}$ showing a sharp decline of writing activity on birchbark, which happened at the turn of the thirteenth century; see Schaeken (2012a, pp. 219-223), who suggests a number of historical events and circumstances that may have caused the 'epistolary crisis' around the year 1200 .

\subsection{Geographical distribution}

As already noted by Vermeer in his review of the ninth volume of $N G B$, it is to be regretted that the $N G B$ series only covers Novgorod and Staraja Russa: "If some way could be found to include texts from elsewhere, the value of the series would be considerably enhanced" (Vermeer 1995, p. 109). Fortunately, the eleventh volume of $N G B$ also contains editions of the nineteen birchbark finds from Toržok, which were excavated during the years 1985 and 1999$2001 .^{7}$ However, if we take the period covered by NGB 12 (2001-2014), it would have been a good opportunity to add editions of the new birchbark finds from Moscow (nos. 2 and 3, found in 2007), Smolensk (no. 16, found in 2009) and Mstislavl' in Belarus (no. 2, found in 2014). ${ }^{8}$ As for texts which were unearthed in Novgorod and Staraja Russa in the last two excavation seasons of 2015 and 2016, preliminary editions are available already (Gippius and Zaliznjak 2016; Gippius et al. 2017). In 2015 ten birchbark documents were discovered in Novgorod (N1064-N1073). In the same year, two new texts were found elsewhere: again, one in Moscow (no. 4), and another in a new place, Vologda (no. 1), which is now the northernmost location where a birchbark document has been discovered. The 2016 season brought to light sixteen new texts from Novgorod (N1074-N1089) and one from Staraja Russa (no. 46). If we count all finds since 1951 in all different places (including cities that have not yet been mentioned: Pskov, Tver', Rjazan', Vitebsk in Belarus and Zvenigorod Galickij in Ukraine), the corpus of birchbark letters now totals 1195 items. The vast majority-more than $90 \%$ have been found in various sites in Novgorod itself. If one includes birchbarks written in other cities in the Novgorodian lands or in the same historical-linguistic region as Novgorod (Staraja Russa, Toržok, and initially also Pskov) they account for no less than $97 \%$ of the

\footnotetext{
${ }^{6}$ See Zaliznjak (2002, p. 608), who gives a very similar graphic on the basis of the data through 1999 (cf. the adapted figure in Schaeken 2012a, p. 217).

${ }^{7}$ See NGB 11, pp. 120-137, and Malygin (2011). No. 14 from Toržok, a fragmentary business letter found on 9 August 2000, turned out to be the thousandth birchbark document unearthed in Old Rus' territory (NGB 11, pp. 129-130).

${ }^{8}$ On Moscow no. 3 - the longest text on birchbark, approx. 370 words - see the edition by Gippius et al. (2011). As far as I know, the other texts mentioned have not yet been published.
} 


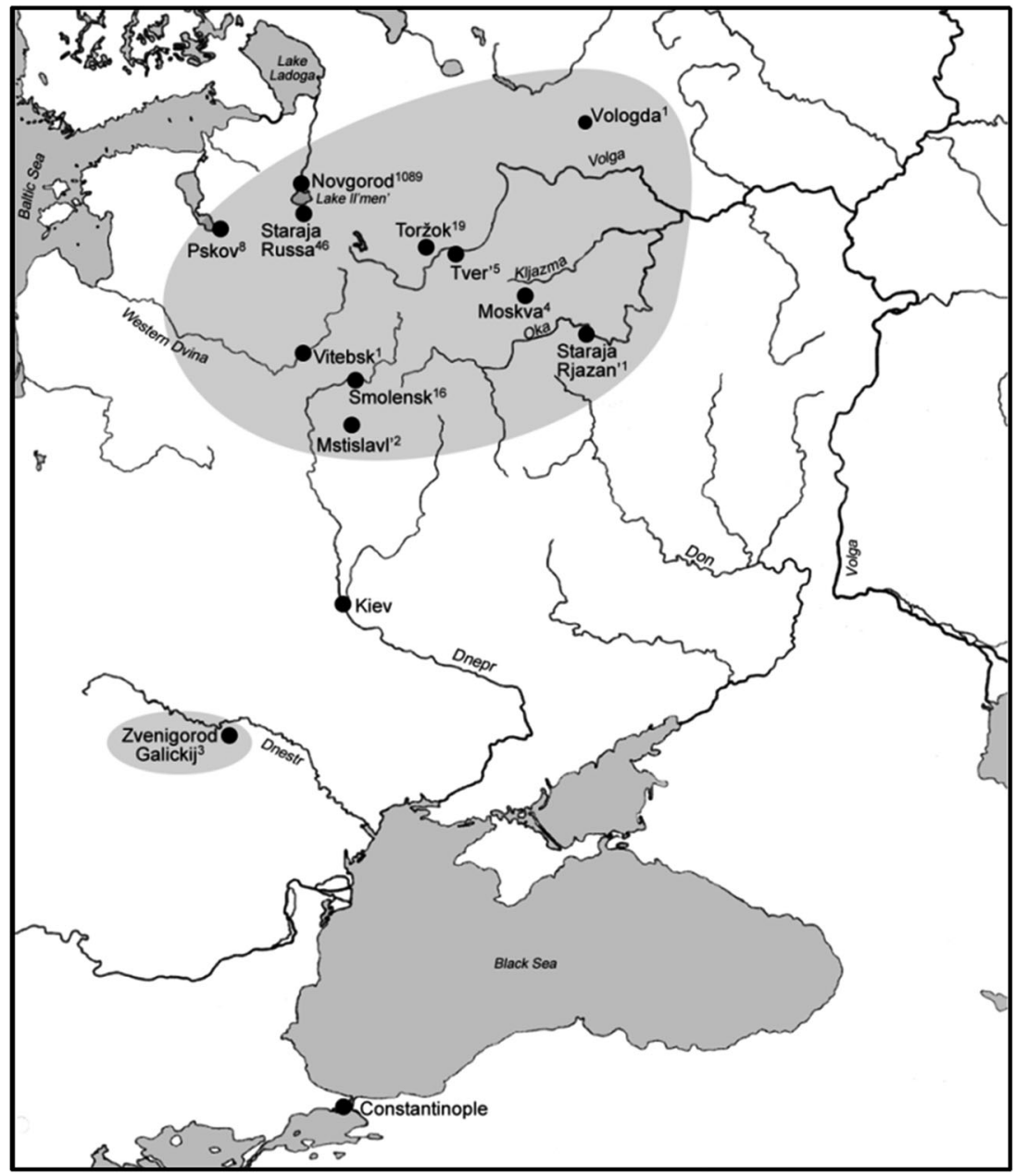

Fig. 2 Geographical distribution of birchbark documents up to and including 2016

corpus. See Fig. 2, which shows the geographical distribution of birchbark finds up to and including $2016 .{ }^{9}$

\subsection{NGB 12 in focus}

It is absolutely clear that over the past sixty-five years, year after year, the 'living corpus' of birchbark documents has become one of the main primary sources for the study of the history of the Russian language and its society in medieval times. NGB 12 brings together many new insights which have been developed over the last decade. Admittedly, the majority of the twenty-first-century finds from Novgorod and Staraja Russa-119 out of 155 , to be precise-have already been published in Zaliznjak's (2004a) monumental Drevnenovgorodskij dialekt $(D N D)$ and / or in the annual preliminary editions in the journal Voprosy

\footnotetext{
${ }^{9}$ Map adapted from Schaeken (2012b, p. 20).
} 
jazykoznanija (2002-2015). ${ }^{10}$ Nevertheless, the new volume has many new things to offer. To begin with, we now have professional drawings for each document. Photos of some of the new finds have been made available on http://gramoty.ru, which will be updated in the near future, as announced in the edition (NGB 12, p. 10). ${ }^{11}$ Second, refinements of readings have been provided in comparison to earlier editions in DND (N931, N932, N934, N937, N943 and N948; see ibid., p. 275). The same holds for the preliminary publications in Voprosy jazykoznanija; see, for instance, updated interpretations in the case of N916 (with reference to Bobrik 2008), N936 (treated below, Sect. 4.2), N942, N944, N954 (see below, Sect. 2.3) and N994.

In the remainder of this paper, the main merits of NGB 12 will be discussed in more detail. Section 2 deals with a general overview and highlights some specific findings, not only with regard to the new data presented in NGB 12, but also the extensive chapter with corrections and comments by Gippius and Zaliznjak on birchbark texts published in earlier volumes of the $N G B$ series; (ibid., pp. 195-275). ${ }^{12}$ The importance of this chapter should not be underestimated: it includes an update of no less than 205 birchbarks, some of which are not even included in DND. The chapter clearly shows that the field of research is constantly progressing (and quoting a birchbark letter on the basis of DND without checking NGB 12 first might court disaster). This development will be highlighted further in Sect. 3, which concentrates on a relatively new field of focus relating to the birchbark documents: their historical-pragmatic context. Another new insight provided by NGB 12 is that the analysis of social networks which can be deduced from the birchbark corpus is worth investigating in more depth in future research. This will be addressed in Sect. 4.

\section{General overview and highlights}

\subsection{History speaks}

Going through the list of comments in NGB 12, we first notice some birchbark texts that are of particular historical importance. To begin with, the new reconstruction of N88, dating roughly from the period 1120-1140 (ibid., pp. 201-205; see also Gippius 2009), provides us with the incipit of the letter: 'From the prince to Ivan and to Petrila'. Based on information from the chronicles, these people have now been identified as prince Vsevolod Mstislavič and the leaders of two rivaling boyar clans from different parts of the city: Ivanko Pavlovič (Ljudin End) and Petrila Mikul'čič (Nerev End). Another important figure shows up in the

\footnotetext{
${ }^{10}$ Both DND and the preliminary editions in Voprosy jazykoznanija do not include the following 36 new birchbark finds: N921, N925, N941, N951, N953, N969, N971, N972, N975, N981, N984, N987, N990, N991, N993, N1003, N1008, N1010, N1017-N1019, N1028, N1030, N1034, N1036, N1038, N1039, N1043, N1044, N1046, N1048, N1049, and Staraja Russa nos. 41, 42, 44 and 45. These finds are mainly fragments, some of which consist of only a few letters. By the way, one of these tiny pieces, N969 (ca. 1340-1360), which reads ... abolo $[\check{s}] \ldots$ or ... abolo $[c]$... and has no further interpretation in the edition (NGB 12, p. 80), very much resembles na boloce 'to the little marsh' in N928 (ibid., pp. 21-22); a reconstruction ( $n$ )a bolo[c](e) for N969 seems quite plausible.

${ }^{11}$ Data from http://gramoty.ru are included in the online Russian National Corpus; see http://www. ruscorpora.ru/search-birchbark.html. For photos of some recent birchbark texts from Staraja Russa, see the online database at http://www.novsu.ru/archeology/db.

${ }^{12}$ This chapter includes a few incorrect references: the newly reconstructed word xartija 'parchment' in N90 (ibid., p. 205) has a parallel form in N992, not N982; "No. 219" (ibid., p. 207) is evidently N129; "No. 416" (ibid., p. 240) is N430.
} 
new reading of N302: Jakov Fedorovič, who was chosen posadnik in 1416 (NGB 12, pp. 222 223). The comments on N724 constitute an article in themselves (ibid., pp. 258-268; see also Gippius 2015) and argue against an alternative interpretation by Petruxin (2009). According to the edition (DND, pp. 350-354), the persons Zaxar'ja and Andrej mentioned in the text are the Novgorod posadnik Zaxar'ja (1161-1167) and a prominent figure in early Russian history-Grand Prince Andrej Bogoljubskij, who ruled in Vladimir from 1157 to 1174. The author of N724, Sava, refers to a larger historical event - a conflict between Novgorod and the principality of Vladimir-Suzdal' about tribute-collection on the northeastern periphery of the Novgorodian lands. Petruxin not only disputes the historical interpretation but also questions crucial chronological and paleographical aspects of the document. His main arguments are refuted convincingly in NGB 12 by Gippius and Zaliznjak.

As for the occurrence of historical figures in the new birchbark texts, we find Smen, the addressee of N963, who can be identified as the Novgorodian archbishop Simeon (in office between 1416 and 1421; ibid., p. 74). Also, N933 is an instruction from 'posadnik Ivan', who might be either Ivan Lukinič Ščoka (elected 1438) or Ivan Aleksandrovič (died 1417; ibid., p. 31). In addition to these identifications, I would like to point out that the list of individuals in N935 (ca. 1180-1200) includes a certain Griga, a name that occurs only twice on birchbark. ${ }^{13}$ In the famous 1189-1199 (probably 1191-1192) Treaty of Novgorod with Gotland and the German Cities a Russian envoy called Griga is mentioned at the beginning of the document: Poslalъ esmь posla svoego Grigu na sei pravdě 'I (Prince Jaroslav Vladimirovič) have sent my envoy Griga to (conclude) these terms' (Valk 1949, pp. 55-56; Janin 1991, p. 81). In principle, this Griga might be the same person as the one in N935, especially since the Treaty also specifies the name of the posadnik Miroška (Nesdinič), who appears in N936 (ca. 1160-1180) and elsewhere on birchbark; see below, Sect. 4, on the relationships between the names mentioned in both birchbarks.

Section 4 also discusses other historical figures who make their appearance in the new finds. In Sect. 4.2 new insights into the economic history of Novgorod will be discussed, especially with regard to domestic and international trade relationships in the mid-twelfth century. In this respect, Staraja Russa no. 39 deserves special attention:

'A bow from Grigor'ja to Jermola and Ozěkěj. I have sent to you six barrels of wine, [filled] to a finger's length [from the top]. And you check it carefully, and sell them like those others, under the same conditions. [And if you have sold them,] send back the proceeds. And don't give my servants (?) the money; send it along with the debt.' [Staraja Russa no. 39, ca. 1380-1400; NGB 12, pp. 167-170] ${ }^{14}$

According to the editors, this is the first time that wine is mentioned on a birchbark, in a text dating from the end of the fourteenth century (NGB 12, p. 169). However, wine-a product that was imported either from the West (ultimately, the Rhinelands) or from the Byzantine Empire-is already mentioned in a birchbark letter that was found in 1980: N586, which is almost three centuries older than no. 39 from Staraja Russa (ca. 1100-1120): 'From Něžatacherries and wine and vinegar and flour; Ivan's coat; and a frying-pan' (DND, pp. 266-267). See now also N1005 from the mid-twelfth century (NGB 12, pp. 105-106), which announces the arrival of wine and thirty pieces of glassware from Velikie Luki, about two hundred and fifty kilometers south of Novgorod.

\footnotetext{
${ }^{13}$ In the index of NGB 12, p. 179, Griga in N935 is listed (erroneously?) along with Griga in N161, a later document from the beginning of the fifteenth century.

${ }^{14}$ Unless stated otherwise, this and other translations in this paper are taken from an updated and extended English version of Schaeken (2012b): Schaeken (forthc.), Voices on birchbark. Messages from medieval Russia: daily life and communication.
} 


\subsection{Linguistic news}

Letter no. 39 from Staraja Russa also offers new linguistic insights. Grigor'ja wants to ensure that all the wine he is sending actually arrives at its destination, so he specifies the depth to which the barrels are filled; in normalized spelling: kakr palecь xvati (NGB 12, p. 167), '[filled] to a finger's length [from the top]'-literally, 'as the finger reaches [xvati]'. The editors point out that this passage explains the semantic connection between two very different meanings of the verb xvatit', viz. 'grasp, grab' and 'be enough, sufficient'. It illustrates that the issue of 'enough or not enough' can imply whether a hand, finger or instrument can reach a certain object or surface: Questions of the type Is the barrel full already? Should I add any more wine? may well have been answered using the words Uže xvatit or just Xvatit! '[it] reaches'. Thus, the word xvatit could easily be reinterpreted as 'enough' and phrases of the type mne xvatit 'I have enough' could be formed, which was impossible under its earlier meaning. (ibid., pp. 169-170). ${ }^{15}$

The new texts do not only provide new observations in the field of historical semantics, but on all linguistic levels. N1047 (ca. 1100-1120; ibid., pp. 148-149) offers an early example of šokan'je, which confirms that this dialectal feature was not restricted to the Pskov area; together with some other instances on birchbark (see DND, p. 52, including N931) this new piece of evidence shows that the phenomenon was also not uncommon in the Old Novgorod dialect. ${ }^{16}$ Another important phonological insight is that the fall of weak jers may already have been an optional feature in the last decades of Early Old Russian; see below, Sect. 4.3, on Jakim's innovative language. Similarly, N1011 (ca. 1140-1160; NGB 12, pp. 110-111) shows that the spread of plural endings of the $a$-declension to other declension patterns set in much earlier - by as much as two hundred years! - than previously assumed. In this document we encounter the locative plural ending - axъ in the $o$-stem words nožb 'knife' and ožerelbe 'necklace'. Also more than two centuries older than recorded in other historical documents is the absence of the reflexive -sja in the syntactic construction a tvorjatb i pe(re)stavivzše 'and they believe he's dead' in N1020 (ca. 1160-1180; ibid., pp. 117-118; cf. also p. 143 on N1045); pe(re)stavivъše instead of pe(re)stavivъšesja (from perestavitisja 'pass away') in constructions with a participle is still characteristic for present-day northwestern Russian dialects.

\subsection{Genres and classics}

All known birchbark genres are represented in the new set of documents. As always, there are many letters and notes that deal with commerce, finance, administration and law. These

\footnotetext{
${ }^{15}$ On Staraja Russa no. 39 and the deictics behind the perfect tense 'I have sent to you ...' see also Schaeken et al. (2014). As for the different meanings of xvatit', a semantic parallel can be drawn with the Dutch verb reiken 'reach' and the adjective toereikend 'enough, sufficient'. Cf. also German, where we find reichen and aus-, zureichend, as well as es reicht 'it's enough' and es reicht mir! 'I've had enough!' - In the case of other birchbarks, semantic parallels in Germanic can also be useful to clarify the meaning of specific lexemes. For instance, the hypothesis that the hapax prisunuti in N1045 may have the meaning "дать взятку" (NGB 12, p. 143) 'slip (on the sly), give secretly, give quietly' (cf. Modern Russian podsunut') can be corroborated with Dutch toestoppen and German zustecken, consisting of stoppen/stecken $=$ sunuti and the prefix toe- $/ z u-=$ pri- (in the meaning of attachment or addition). Historical dictionaries of both languages give evidence of the semantic connotation of secrecy (see http://gtb.inl.nl, s.v. toestoppen, and http://woerterbuchnetz.de/DWB, s.v. zustecken).

${ }^{16}$ See now also the reanalysis of N167 in NGB 12, pp. 208-209, with a new example of šokan'je, and N88 and N211 (ibid., pp. 202-203, 213), including two new reconstructed verb forms with dialectal $k l<* t$. Incidentally, N1047 beautifully shows the origin of the Modern Russian negation netu < ne e(stb) $t u$. In normalized spelling the letter reads: Ali ti estb tu, a vzzьmi na nemь dъvě grivbně. Ali ti ego ně tu, a tako ze [= že ( mi vъzdai 'If he is there, take two grivnas from him. If he is not [ně < ne e] there, let me know'.
} 
typical examples are not always easy to recognize and decipher, as is the case for N1052 (ca. 1320-1340; NGB 12, pp. 152-153), which only consists of some sort of drawing and four characters, separated by vertical strokes: ' $\mathrm{I}|\mathrm{O}| \mathrm{K} \mid \mathrm{L}$ '. In the edition, Gippius offers an ingenious hypothesis, according to which the signs should be read as a sequel of numbers: ' $8,70,20,30$ '. The total sum of 128 can be interpreted as referring to the ansyr', a weight unit consisting of 128 zolotniks, which was used to weigh silk. On the basis of N288 (DND, p. 541), in which colors of silk, measured in zolotniks, are mentioned (... a zolotnik of green silk, another of red, a third of green-yellow ...'), it is conceivable that N1052 refers to different colors of silk ('an ansyr' of silk, made up of four colours') in the same way as N288. This hypothesis, by the way, led to a reanalysis of N686, which was still lacking a credible interpretation of the enigmatic message ' 128 in the simple, and in the other 96 ' (DND, p. 383). The new explanation of N686 (NGB 12, pp. 256-257) illustrates how making sense of the birchbark letters is an ongoing process; it took thirty years to gain a plausible interpretation of N686, thanks to the discovery in 2014 of a tiny piece of birchbark with four characters on it.

Testimonies of church affairs, religion and magic are also represented in the new finds. See, for instance, the above-mentioned letter N963 (Sect. 2.1), in which peasants petition the archbishop because their church has no priest, and they feel that the right candidate for the office is one of their own number, the deacon Oleksadr. Incantations against fever can be found in N930 (ca. 1400-1410) and N1022 (ca. 1160-1180), both mentioning the archangel Sichael (NGB 12, pp. 24-26, 119-120). ${ }^{17}$ Or take N973 (ca. 1240-1260), which consists of the unique spell 'Gehenna's Fire' (geonegone; ibid., pp. 82-83). There is even a curse from the early twelfth century inscribed on a birchbark basket and meant for anyone who might come up with the idea of messing around with 'Voibuda's basket' (N957, ibid., pp. 60-62). ${ }^{18}$ Finally, among the older finds that have been reanalyzed in the edition, N450 (ca. 11801200) is of particular importance (ibid., pp. 241-243). The fragment, written unusually on a round piece of birchbark (see the drawing in NGB 7, p. 51), appears to be the beginning of Hebr. 2:13: 'Behold I and the [children] (which God hath given me)'. Historical evidence shows that the text may be connected to prayers for the Absolution of the dead; the proposed reconstruction of $\mathrm{N} 450$ would make it the oldest attestation of this particular text type in Rus' (NGB 12, p. 242).

NGB 12 also includes texts of a more personal character. Some of these are bound to become classics, like N954, N955 and Staraja Russa no. 40, which are worth quoting:

'A letter from Žiročko and from Těško to Vdovin. Say to Šil'ce: "Why are you damaging ${ }^{19}$ other people's pigs? Nozdr'ka has made [this] known. And you have disgraced

\footnotetext{
${ }^{17}$ The left side of the birchbark on which N930 is written shows traces of stitching and appears to be the upper half of a sheet that was torn out of a birchbark book. There is only one known birchbark text that is formatted as a book: N419 (ca. 1280-1300), made from three pieces of bark folded in half. Like N930 (see also Gippius 2005a), the content of N419 is of a religious nature, viz. two well-known prayers from the evening service (see DND, pp. 523-524). Among the new finds, there is another text that originally may have consisted of more than one, probably two, sheets: N929 (ca. 1280-1300), a complicated letter about some sort of conflict over property (NGB 12, pp. 22-24).

${ }^{18}$ It was not Voibuda who wrote the curse because at the end of the inscription it says: 'And Ševko wrote [this]'. Apparently, the nickname Ševko (cf. Modern Russian šit' 'to sew') refers to the weaver of the basket (see also the new comment on N123; ibid., p. 206). Cf. N1056 (ibid., pp. 157-158), which contains a similar inscription: 'Danilo's basket. And Petrilo wove [š i(le)] [this]'.

${ }^{19}$ The interpretation of Šil'ce's precise acts hinges on the meaning of the verb pošibati, which is translated imprecisely here as 'damage', from a root meaning 'hit, push, poke'. The most straightforward explanation seems to be that Šil'ce has committed bestiality; another is that he has been casting spells to cause an epidemic among his enemies' cattle.
} 
the entire Ljudin End. [There has been] a letter from the other side [of the river]. It was about horses, that you have done the same [with them].' " [N954, ca. 1120-1140; ibid., pp. 50-54; translation by Dekker 2016, p. 127]

[Upper part] 'From Miluša to Marena. Big Braid, may she/let her marry Snovid. [Lower left] Marenka, let the vagina drink and the clitoris.

[Lower right] Thus spoke Miluša: Give yesterday's 2 grivnas.' [N955, ca. 1140-1160; ibid., pp. 55-59; translation by Collins 2011, p. 39] ${ }^{20}$

'A bow from Oksinija and Onanija to Rodivon and my sister Tat'jana. Come to the city before this Sunday. I am to give my daughter [in marriage], and my sister should be an attendant. And I make a great bow to my lord Rodivon and my sister.' [Staraja Russa no. 40, ca. 1380-1400; NGB 12, pp. 170-172]

Some well-established classics on birchbark have been reanalyzed in the NGB 12 chapter with corrections and comments on texts that have been published in earlier volumes of $N G B$ (and $D N D$ ). We already mentioned N724 (Sect. 2.1), which is of great historical importance. Another one is N531 (ca. 1200-1220), a long private letter from Ana to her brother Klimjata about a complicated legal episode, in which she expresses herself in an emotional tone and unceremonious language ( $‘$... you called her a slut and her daughter a whore ... since you have made that claim, prove it ... if there turn out to be witnesses to that, I am no sister to you, and no wife to my husband; then you can kill me...'). Several interpretations have been advanced to explain the real-world scenario that lies behind this complicated letter and the editors of NGB 12 (pp. 247-250) once again return to some crucial passages in the text. They also reanalyze N377, which is short and straightforward; Mikita asks his fiancée: 'Marry me! I want you, and you me. And Ignat Moiseev is witness to that ...'. Scholars who are familiar with this popular text from the late thirteenth century probably know the fiancée as Ana since in DND, pp. 494-495, the incipit of the letter reads 'From Mikita to Ana'. However, a renewed scrutiny has resulted in the new proposal 'Malanija' instead of Ana (NGB 12, pp. 232-233).

Undoubtedly the most famous character on birchbark is Onfim. Seventeen of Onfim's birchbarks have been found: they date from the mid-thirteenth century. Twelve of these contain drawings, with or without written text, and the other five a few words only. Judging from the style of his drawings and the kinds of texts he writes, he must have been six or seven years old. ${ }^{21}$ Onfim's birchbarks, which also include text, have been published in DND (pp. 475478). In NGB 12 (p. 212), a new readings of N206 is offered. The birchbark contains, apart from syllable exercises and drawings, a sequence of four letters with a titlon on top. According to DND (p. 477), the sequence might be read as a number (in this case 1263), which many scholars have taken to denote a year, in fact the current year of Onfim's exercises. However, after decades of lively discussion about the precise meaning of this birchbark, a totally new interpretation has now been proposed in NGB 12, which is likely to bring the debate to an end. The sequence of four letters turned out to be an abbreviation which refers to the first words of the six-o' clock troparion Iže v šestyj den' že $i$ čas [...] 'Who on the sixth day and hour [...]'. This must have been a well-known text to Onfim, who was used to practicing

\footnotetext{
${ }^{20}$ See also Collins (2011) on this remarkable marriage document. The upper layer of the birchbark has disappeared, but it clearly contained an icon-like drawing (see NGB 12, pp. 54-55), leaving an imprint on the lower layer which is still intact. It is vaguely visible to the right of the text: a cross with a woman and a man on either side. In relation to the text, it seems to be the depiction of a wedding ceremony.

${ }^{21}$ See Janin (1998, pp. 55-70), and Rybina (1998), in which other drawings on birchbark, wood, stone, bone and artefacts from Novgorod are also presented.
} 
his writing skills by reproducing liturgical texts that he may have known by heart (see also N207 and N331, which contain short passages of the Psalms). The meaning of the word that follows after the abbreviation, naso, is still considered inconclusive; in the new reading, it is suggested that the first syllable might have originated from na krestě 'to the cross', and the second from sogrěšenii '(of our) trespasses', both alluding to the continuation of the six-o'clock troparion: [...] na kreste prigvoždej v rai derznovennyj Adamov grex, $i$ sogrěšenij našix rukopisanie razderi, Xriste Bože, i spasi nas '[... ] nailed to the Cross the sin that Adam dared in Paradise, tear up the record of our trespasses, O Christ God, and save us'. However, naso in the sense of 'us / our' (with Onfim's typical spelling $ъ \rightarrow o$; see DND, pp. 477-478) would be a good fit for the beginning of the nine-o'clock troparion Iže v devjatyj čas nas radi plotiju smert' vkusivyj ... 'Who at the ninth hour tasted death in the flesh for our sakes'. Thus, it may well be that the beginning of N206 is a hybrid quote from both troparia. Even the tiny fragment $\mathrm{N} 208$ (... gvoz ... ... $x y$ n ...), which is also attributed to Onfim, might belong to the same set of hymns. DND (p. 477) already speculated that it may contain some words from a prayer, like voleju prigvozdise 'nailed by the will', grěxy našę 'our sins' (p. 477). It is hard to believe that the occurrence of prigvoždej 'nailed' and sogrěšenii našix 'of our sins' in the continuation of the beginning of the sixth troparion as reflected in N206 and the proposed reconstruction of $\mathrm{N} 208$ is pure coincidence.

\subsection{Berestology meets epigraphy}

On several occasions, the analysis of birchbark letters published in NGB 12 has benefited from recent research that is concerned with another witness of lay literacy in Old Rus', namely graffiti on church walls. Specialists have been continuing earlier epigraphic investigations in the churches of Novgorod, most notably St. Sophia, and explored other locations as well, including places as far away as Istanbul, Bethlehem, and even in France. ${ }^{22}$ Since the publication of Zaliznjak's contribution to the field of epigraphy in NGB 11 (Zaliznjak 2004b), new insights gained from evidence on birchbark and church walls have been correlated in a more systematic way. This interdisciplinary approach has enhanced both areas of study, also with regard to dating graffiti more accurately on the basis of detailed paleographic patterns established for birchbark documents. ${ }^{23}$

A telling example of the fruitful interaction between berestology and epigraphy is N1000, which was already cited at the beginning of this paper. The name of one of the senders of the letter, Kyas, appears to be of Turkic rather than Slavic origin (NGB 12, p. 100). The same name, in the form of the patronymic Kijasovič, was identified on a fragment of a plaster wall from the Cathedral on the Protoka in Smolensk (see Gippius and Mixeev 2013a, pp. 180183). An autograph on a church wall of St. Sophia in Novgorod also turned out to be of Turkic provenance: Sandus (idem 2011, pp. 44-46). Furthermore, the new finds on birchbark reveal the Turkic patronymic Gjulopinič in N926 (ibid., p. 46, fn. 30), i.e. son of Gjulopa, a name that is attested in N729 (see also below, Sect. 4.4). Finally, a reanalysis of N71 (Gippius 2012; NGB 12, pp. 200-201) offers the new reading (in normalized spelling) Ilbdatino selišče, i.e.

\footnotetext{
${ }^{22}$ Recent publications on the Cyrillic inscriptions in Hagia Sophia in Istanbul are Artamonov et al. (2009, 2010, 2012) and Artamonov and Gippius (2012). East Slavic, including Old Russian, graffiti found in the Basilica of the Nativity in Bethlehem are dealt with in Artamonov et al. $(2013,2016)$. For two recent discoveries of Old Russian inscriptions from the twelfth or early thirteenth century in France (in churches located at the southern- and westernmost pilgrimage roads to Santiago de Compostela), see Brun et al. (2014) and Gordin and Roždestvenskaja (2016).

${ }^{23}$ In this respect, Mixeev (2010, p. 92) rightfully observes that many authors of Novgorodian graffiti must also have written on birchbark; therefore, the parameters of extrastratigraphical dating are in principle the same for birchbark documents and graffiti.
} 
Fig. 3 (a) Monogram in N797, (b) monogram in N797 decomposed, (c) monogram of deacon Dušen'

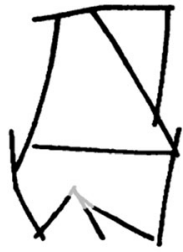

$a$

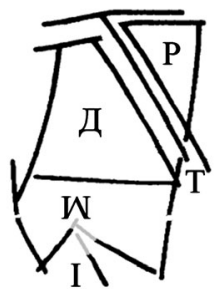

b

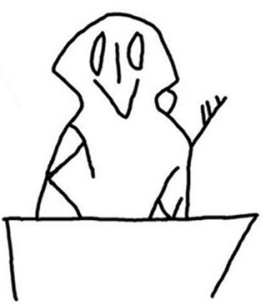

$c$

the village of a person with the Slavicized Turkic name Il'djata. All this new onomastic evidence from the twelfth and early thirteenth centuries, on birchbark and stone, shows that the presence of individuals with Turkic roots in Novgorodian lands was not something unusual in pre-Mongolian times (ibid., p. 201).

There is more new onomastic data on birchbark that can be corroborated by the results of recent epigraphic research. For instance, the first element of the name Goimer in N1004 (see below, Sect. 3) now finds a parallel in Naš [bgo]i, an early Glagolitic inscription in Novgorod's St. Sophia (Mixeev 2012, p. 78). In the same cathedral, a second attestation of the name Naško was discovered; the first one appeared in N966 (Gippius and Mixeev 2013b, pp. 158-159; NGB 12, pp. 77-78). The reconstruction of the name Kulotka (Kulot ...) in fragment no. 45 from Staraja Russa (ibid., p. 176) is once again reconfirmed by a reanalysis of an autograph in St. Sophia, which reads Kulotъka (Gippius and Mixeev 2011, p. 46). As for previously known birchbark texts, the tentative interpretation of Lbiske as a personal name in N321 can now be corroborated by the name Lzbistzko in an inscription in the same cathedral (idem 2013b, pp. 163-164; NGB 12, p. 223).

Recent epigraphic research has also drawn attention to a couple of cases in which the names of people who appear on birchbark might be identified as being the same individuals who left their marks on the walls of a house of God. In the Hagia Sophia in Istanbul there are two inscriptions that have the names Grečin ('Holy Sophia! Grečin wrote [this]') and Olisej in them ('Lord, help your servants ... Olisej ...'). We only know of one person with the same name who was alive during the period to which the inscriptions are attributed (second half of the twelfth to early thirteenth century): the famous Novgorodian boyar, priest and iconpainter Olisej Grečin, who figures in the chronicles and on birchbark (see below, Sect. 4.3). It is quite possible that this Olisej Grečin was the author of the graffiti in the Hagia Sophia (Artamonov and Gippius 2012, p. 44; see also Artamonov et al. 2012, p. 285). Another, though rather speculative case is the eleventh-century autograph 'Efrem the Syrian' carved on the walls of Novgorod's St. Sophia. This Efrem, who was probably also responsible for inscribing the words parexъ mari (a Slavic adaptation of the Classical Syriac formula 'Bless, O Lord') in St. Sophia, might be identified as the monk Efrem who wrote birchbark letter N605 (see Gippius et al. 2012, p. 281, fn. 25, and now also Temčin 2015).

A last remark on the productive collaboration between epigraphists and berestologists concerns the interesting occurrence of more than a dozen monograms in St. Sophia, not counting the usual ones bearing the name Jesus Christ (see Gippius and Mixeev 2013b, pp. 154-156). The monograms consist of personal names (Lazor', Stefan, Luka, Putka, etc.), of which all letters or a part of them (consonants only, like in the case of a certain Mečislav) are organically combined in the form of a figure. In one particular case the monogram even has an anthropomorphic appearance; see Fig. 3c, which represents the name Dušen' and his profession, viz. deacon ( $d_{b} a k[6]$ Dušbn[b]; ibid., p. 156).

Gippius and Mixeev (2013b) argue that the monograms have a Byzantine origin, although they may have been used in St. Sophia merely as a 'graphic play' of some young clergymen 
who lived in the second half of the eleventh century and were exploring the possibilities of their newly acquired writing skills. In this respect, I would like to point out that N797 (NGB 11, p. 26; DND, p. 455) probably also contains an example that belongs to the playful category of monograms drawn by inexperienced writers practicing their skills. N797 is dated to the last quarter of the twelfth century and is not as old as the monograms in St. Sophia, but there is no compelling reason to assume a temporal restriction on this type of practice. The monogram is represented in Fig. $3 \mathrm{a}^{24}{ }^{24}$ which also shows it in a decomposed form (b). The base is clearly the letter $D$, like in the case of deacon Dušen's ingenious signature. The letters $R$ (at the far right) and $M$ (below and upside down) are rather straightforward. The ligature of $D$ plus $R$ might also include the letter $T$, as suggested by S. M. Mikheev (p.c.), and $M$ below seems to incorporate an additional letter, most likely $I$, as proposed by A. M. Lubotsky (p.c.). The combination $D, R, M$, and probably also $T$ and $I$, perfectly fits in with the interpretation of the rest of the very fragmented text, which reads as follows in its diplomatic transcription: $\bar{w} о т ъ \partial ъ-m ъ \partial-\ldots[\mu] \ldots \partial$ (NGB 11, p. 26). ${ }^{25}$ According to the editors, the writer was practicing the incipit of a letter. He first wrote $\bar{w}$ (i.e. ot represented as the ligature omega $+\mathrm{t}$ ) 'from', but then decided that he preferred the alterative spelling om $\measuredangle$ (i.e. ot $\measuredangle$ ). The following letters, which include $d, \tau$, and $m$, most probably reveal the name of the author: Drmitrz (ibid.). The monogram's letters support the conjecture that the drawing relates to this name $(D, M, I, T, R$ composed in counterclockwise order $=D[6]$ mitr $[\varangle])$ and N797 seems to have the same author's profile as the one established for the monograms in St. Sophia.

\section{Communication and pragmatics}

The eleventh volume of $N G B$ includes a ground-breaking article by Gippius (2004a) on the pragmatics and communicative organization of birchbark documents. The author shows that, even as a written medium, messages could be 'spoken' (dictated) and 'heard' (read aloud). This oral aspect was not trivial but rather a central part of the communicative event, which influenced the form and meaning of the texts themselves. Messengers often played a key role in the communication between sender and recipient; they are sometimes mentioned explicitly in the birchbark letter, but, even when they are not, internal evidence often shows that they could be more than disinterested conveyors ('letter-bearers'); they could be active participants in the entire written transaction or even the beneficiaries of the business deal with which a letter is concerned. Often, the messengers must have been entrusted with additional information, i.e., they were expected to expand upon or clarify the bare bones of the written text. The orality factor in the communicative event and the special role of the messenger are crucial for a proper understanding of a special text type, which Gippius (ibid.) calls 'communicatively heterogeneous', i.e. letters in which several persons are addressed individually, in ways that are unexpected judging by the information in the incipits. Such letters cannot be read as continuous, coherent wholes; it has been shown that they consist of separate parts, which are not always explicitly demarcated from one another. Such internal divisions and shifts can be difficult to recognize, yet they are critical for an appreciation of the nature of the communicative event. ${ }^{26}$

\footnotetext{
${ }^{24}$ The gray strokes in Fig. 3a are not in the original drawing (NGB 11, p. 26). However, after inspection of a photo of N797, it is clear that the lower bars of the monogram are actually connected with each other.

${ }^{25}$ The final letter $\partial$ perhaps represents the base of the monogram under discussion.

${ }^{26} \mathrm{~A}$ broader theoretical and methodological perspective on Gippius's observations is provided in Dekker's (2016) $\mathrm{PhD}$ dissertation.
} 
The twelfth volume of $N G B$ continues this relatively new historical-pragmatic ('pragmaphilological' $)^{27}$ field of research by discussing birchbark letters which have been reanalyzed over the last decade ${ }^{28}$ and by carefully paying attention to the pragmatics behind the new finds. In the chapter which comments on documents that have been published in earlier volumes of the $N G B$ series, the following birchbarks are particularly important: N286 (NGB 12, pp. 220-221), N497 (ibid., pp. 244-245), N755 (ibid., pp. 269-270), N771 (ibid., p. 270) and no. 5 from Tver' (ibid., pp. 273-274).

Among the new finds, we have already encountered N955 (see above, Sect. 2.3), which according to Collins (2011) has multiple addressees, not all of whom are explicitly identified. In other instances, the heterogeneity of the communicative event is more overt. For instance, N952 (ca. 1160-1180; NGB 12, pp. 46-49) consists of two separate messages in the same handwriting ('A bow from Radko to father [...]' and 'And a bow from Vjačeška to Lazor' [...]'), without any graphic demarcation. The same may hold for the fragment N1017 (ca. 1240-1260; ibid., pp. 115-116), where we find, rather unexpectedly, in the middle of the text the beginning of the incipit formula 'A bow from ...'.

N962 (ca. 1430-1450; ibid., pp. 69-73) beautifully illustrates the hesitation of the author whether or not to specify the individuals who pronounced the utterances that he quotes. In the process of writing, he obviously decided to tag these parts of direct speech by adding their names above the lines: 'The priest says:' and 'Oleksej [says]:'. The author of N1054 was less hesitant in explicitly referring to the people involved in his business, including the messenger of the letter:

'A bow from Mita to Luka and to Fral'. In the boat are 2 loads of hides and a box and a batch of wax; and Kur's small load of hides. Kur! Give a grivna and 3 kunas. To my son one and a half grivnas. [The one] who has the letter has [the] one and a half grivnas.' [N1054, ca. 1260-1280; ibid., pp. 154-156]

In N1004 (ca. 1140-1160; NGB 12, pp. 102-104), the messenger is also mentioned, but not explicitly as such. In one of the short notes on the back of this birchbark we read: 'And that is Goimer-someone who [was] in Chernigov—with [his] wife; I don't remember [her] name'. Another note on the same side says: 'And there are 10 rězanas with the birchbark'. Apparently, the sender wanted to point out to the addressee the name of the carrier of the letter as well as the amount of money (while he had to admit that he forgot the name of Goimer's wife). The shortest way of referring to the messenger is by using the pronoun sei 'this [person]', as we can see in N1006 ('And give this [man] eight nogatas') and N1025 ('this Jakim'). ${ }^{29}$

A special case is N997 (ca. 1140-1160; ibid. pp. 95-97), a letter written by Luka on behalf of Něgožir (see below, Sect. 4.2), which on the front of the birchbark contains a message for Těšen ('From Něgožir to Těšen'). Něgožir asserts that his two stallions are free of debt and explicitly mentions the writer of the text—or the writer mentions himself, for that matteras a participant in the business affair: 'And I sold [them] to Luka'. The text continues on the back of the birchbark, in the same handwriting, but is not addressed to Těšen anymore because he is now mentioned in the third person ('And take from Těšen ...'). Obviously, the list of payments on the back are further instructions from Luka (rather than Něgožir) for the person who had to deliver the message to Těšen. A similar scenario might be applicable to

\footnotetext{
${ }^{27}$ See Schaeken (2011, p. 2) and Dekker (2016, pp. 55-58).

${ }^{28}$ See in particular Collins (2011), Schaeken (2011, 2014), and Gippius and Schaeken (2011).

${ }^{29}$ For other instances on birchbark of sei referring to the messenger (N227, N735, N739, N879), see Gippius (2004a, pp. 199-200, 205, 210).
} 
N1012, written by the same Luka, which will be dealt with below, Sect. 4.2. There, we will also discuss N1005, yet another letter written by Luka, although here he is only the author of the text on the front side of the birchbark. The continuation on the back, which is in a different handwriting, was probably composed by his brother Ivan. Although the incipit only mentions Luka as the sender of the letter ('From Luka a bow to father'), both scribes only use dual forms ('the two of us' / 'both'). In various ways, communication on birchbark was often a joint venture and collaborative effort.

Among the new birchbark finds, there is the first example of what seems to be an address (in terms of the names of sender and addressee) written on the back of a letter and obviously meant for the messenger as an aide-mémoire. The letter in question is N1026 (ca. 1160-1180), which is about the purchase of a slave-girl ('... And I took your slave-girl. If the slave-girl is cripple, bring her to my [...]'). The incipit 'From Něžila to Semka' is repeated on the back of the birchbark, which may indicate that it served as an address on the outer side. As the editors point out (ibid., p. 126), this was typical of letters from antiquity, but has not been attested on birchbark before. ${ }^{30}$ The fragment N1055 (ca. 1260-1280) also seems to include an address, but in terms of the location of the addressee '[From X to Y] on Rozvad's Street'. Interestingly, the letter was not found in the street of the recipient, which still exists (ul. Rozvaža), on the Sophia Side, but on the other side, the Trade (or Market) Side (at Carpenter's End). Perhaps the recipient took the letter back to the sender after he had carried out the instruction written in the letter (NGB 12, p. 157). N1055 is another example which shows that communication on birchbark not only happened over long distances (as is the case for the above-mentioned letter N1004 from Chernigov, some eight hundred kilometers southwest of Novgorod) but also within the city of Novgorod itself (cf. N954 above, Sect. 2.3).

\section{The Luka-Ivan network (mid-12th century) and Jakim network (end of 12th century)}

\subsection{Preliminary remarks}

NGB 12 contains a considerable number of remarks in which the editors point out that a certain name which appears in text A can be identified as being the same as the one found in text B. In two important instances the volume pays special attention to the identification of shared names, associated with the two business partners Luka and Ivan's enterprise, and the manifold activities of an individual called Jakim. In these specific cases, which will be treated in detail below, we can be absolutely sure of the identification because the names belong to the sender or author of multiple texts in the same handwriting. Such a group of texts is called a 'block' (blok, see DND, p. 17). In addition, NGB 12 offers many other observations that establish a link between individuals who appear not only in texts written by Luka, Ivan and Jakim, but also in other birchbarks. In turn, these other birchbarks may contain additional names (of senders, recipients or people mentioned in the text), which can be identified as belonging to the same person in yet another document. The degree of plausibility of the identifications varies and depends on a number of parameters. Statements about

\footnotetext{
${ }^{30}$ Repetition of the incipit on the other side of the birchbark, or at least the very beginning of it, also occurs in N1004 (see above) and N1045; both letters are from Luka (see below, Sect. 4.2): ‘+ From Lu' (on the back of N1004) and 'From L' (back of N1045). In the case of N1045, Luka may have changed the side of the birchbark because of the dark color of the side on which he started (NGB 12, p. 142). As for N1004, it is not clear why he changed his mind, but it does not seem that we are dealing with some sort of abbreviated address, as proposed for N1026.
} 
the identification of individuals can be made with relative confidence when the shared name occurs in letters discovered in the same archaeological layers at the same site or adjacent sites, although the level of certainty may be lower in the case of common baptismal names like Ivan, Petr, or Ana. A relatively high degree of plausibility is also present when shared names appear in multiple letters with the same sender and / or recipient or when the person named has a consistent social profile (e.g., engages in the same business), judging from the content of the letters. In some cases, names on birchbark can be linked to individuals known from other historical sources - in particular, the First Novgorod Chronicle.

Here are some examples from NGB 12 of the different types of qualifications (highlighted in italics) for the degree of plausibility of the identification of shared names:

- 'He [Grečin in N935-J.S.] can practically certainly (praktičeski nadežno) be identified as Olisej Grečin [...], who is well known from a series of texts found in Trinity estate A [...]' (NGB 12, p. 33);

- 'To a high degree of probability ( $s$ vysokoj verojatnost'ju) he [Jakim in N935-J.S.] can be identified as the same Jakim, who wrote a series of texts found in the same estate $\check{Z}$ [...]' (ibid., p. 33);

- 'Judging from the chronology and location of the discovery, he [Snovid in N955-J.S.] can presumably (predpoložitel'no) be identified as the same Snovid, who appears (in various roles) in a whole series of texts from the Trinity excavation [...]' (ibid., p. 56);

- 'Tverdjata [in N1000-J.S.] is probably (verojatno) identical to the individual with the same name in text no. 672 [...]' (ibid., p. 99);

- 'Žiročko [in N1000-J.S.] is possibly (vozmožno) identical to Žiročko in no. 954 and / or Žiročka in no. 851' (ibid., p. 99; see also p. 127);

- 'In principle ( $v$ principe), this [the nickname Zuj in N1014-J.S.] might be (mog by byt') the same Zuj as in no. 1024, which is dated somewhat later' (ibid., p. 114).

The choice for establishing a more or a less plausible connection by means of different qualifications, such as the ones cited above, may seem a bit impressionistic and ad hoc, especially for scholars who are not per se experts in the complex field of berestology. Without a doubt, there are good reasons for carefully employing conditionals ranging from 'highly probable' to 'in principle'. However, an analysis of the social networks on the basis of shared names in birchbark texts, which provides a deeper insight into their socio-historical context, would benefit from a more systematic approach, similar to the highly sophisticated way in which paleographic issues have been treated in NGB 10 (Zaliznjak 2000). Perhaps a well-defined set of identification criteria and a fixed number of degrees of plausibility could be established in order to make further progress in this particular matter. ${ }^{31}$

Reading through NGB 12 (or previous editions as well as DND), it is quite a challengesometimes even to the extent that one is fighting a losing battle-to maintain an overview of the many connections established between shared names in different birchbarks. For this reason, a schematic visualization of two larger interconnected networks is presented in Fig. $4 ;^{32}$ one that revolves around the Luka and Ivan blocks (see NGB 12, pp. 144-147), and another

\footnotetext{
${ }^{31}$ To begin with, one might apply three degrees of plausibility: degree 1 - the highest one-for blocks; degree 2 for strong archeological evidence in combination with additional circumstantial arguments (uniqueness of the name, mentioning in chronicles, etc.); degree 3 for archeological evidence without any further clues (a conjecture that is often labelled vozmožno 'possibly' or $v$ principe 'in principle' in the editions).

${ }^{32}$ In $D N D$, blocks and other groups of texts that are closely connected to one or more individuals are clustered together in sections (stat' $i$ 'articles', indicated by a letter plus a number, e.g. 'A 10', ' $\Gamma 25$ '; see DND, p. 228). The networks represented in the diagram offer a larger picture of these social connections by combining multiple blocks and sections.
} 
focusing on the substantial Jakim block (ibid., pp. 137-141). ${ }^{33}$ In total, the diagram reveals there are shared names in 62 out of 146 texts, found in Novgorod between 2001 and 2014 (ibid., pp. 12-165). ${ }^{34}$ In addition, the networks represented in Fig. 4 include thirteen extra texts, which were discovered earlier and published in previous editions of $N G B$ (as well as $D N D) .^{35}$

Against the background of the discussion above, the main drawback of the diagram is that the links between birchbark texts do not distinguish between the different degrees of plausibility of their relationship in terms of shared names. To a certain extent the diagram is a hypothetical reconstruction of all possible connections that can be established; it is still too early to differentiate graphically by means of distinctive links between the texts, for instance by using different colors or line thicknesses. ${ }^{36}$ Nevertheless, the visualization should help the reader of NGB 12 to gain some kind of grasp of the general picture, which clearly illustrates that communication on birchbark was deeply integrated into specific social layers of medieval Novgorodian society. A detailed account of the precise nature and validity of the relationships will be presented below. But first the different types of symbols and links used in Fig. 4 will be explained:

- The names in the nodes can be accompanied by two sets of symbols, either triangular or round in shape, placed before the number of the birchbark text:

- The triangle symbols: indicates that the name mentioned is the sender of a letter; indicates the addressee; and $\boldsymbol{\Delta}$ refers to individuals that are mentioned in the text by the sender (or the author when we are dealing with a note or administrative list that was meant for personal documentation rather than communication by means of a letter).

- The round symbols: o means that Jakim was the text's scribe (Jakim block); - stands for scribe A from the Luka-Ivan network; • refers to scribe B from the same network.

- Links between sender and addressee are represented by a solid line with an arrow $(\rightarrow)$. A dotted line can be in black (---) or grayscale (-- -). Grayscale lines are drawn between networks. Black dotted lines indicate the relationship between X, mentioned in the text $(\mathbf{\Delta})$, and $\mathrm{Y}$. Y can be either the sender of a letter in which $\mathrm{X}$ is mentioned or another individual that appears in the same text. For instance, if we look in the upper left corner of Fig. 4, we see that Gavrila is mentioned in N935 and N989. In the case of N935 there are dotted

${ }^{33}$ Three additional, though more simplified visualizations of social networks can be found in Schaeken (2012b, pp. 160-165): the Pavel-Ivan-Něžata network, mainly discussed in sections A 19 and A 20 in DND (pp. 262270); the Petr-Jakša-Marena network, mainly discussed in Б 22 in DND (pp. 313-322) and referred to in Fig. 4; and the Grigorij network, mainly discussed in $\Gamma 56$ in DND (pp. 595-602).

${ }^{34}$ NGB 12: N922, N923, N927, N935, N936, N943, N952, N954, N955, N974, N976-N979, N982, N983, N986, N988, N989, N992, N994-N1000, N1004-N1007, N1009, N1012, N1014, N1015, N1020, N1021, N1023-N1025, N1027-N1029/980, N1030-N1042, N1045-N1047, N1049, N1050.

${ }^{35}$ NGB 9: N621, N630, N654, N657, N672, N685; NGB 10: N710, N735; NGB 11: N799, N805, N850, N851, N879.

${ }^{36}$ Alternatively, specialized software for visualizing and analyzing social graphs might be applied, such as the popular open-source platform Gephi (https://gephi.org) for instance. The platform is used by the Visualizing Historical Networks Website at the Center for History and Economics at Harvard University (http://www.fas.harvard.edu/ histecon/visualizing) and includes the project 'Vindolanda: A Visual History'. This pilot project focuses on the well-known corpus of thin wooden writing tablets with records and personal messages from and to the fort Vindolanda in Roman Britain (see http://vindolanda. csad.ox.ac.uk) and contains a diagram of a hypothetical reconstruction of one particular network (http://www.fas.harvard.edu/ histecon/visualizing/vindolanda/network.html). Typologically, the contents of the Vindolanda tablets are rather similar to the birchbark corpus (see Franklin 2002, pp. 42-45; Gippius 2004a, pp. 228-229; Schaeken 2012a, p. 207, fn. 17). 


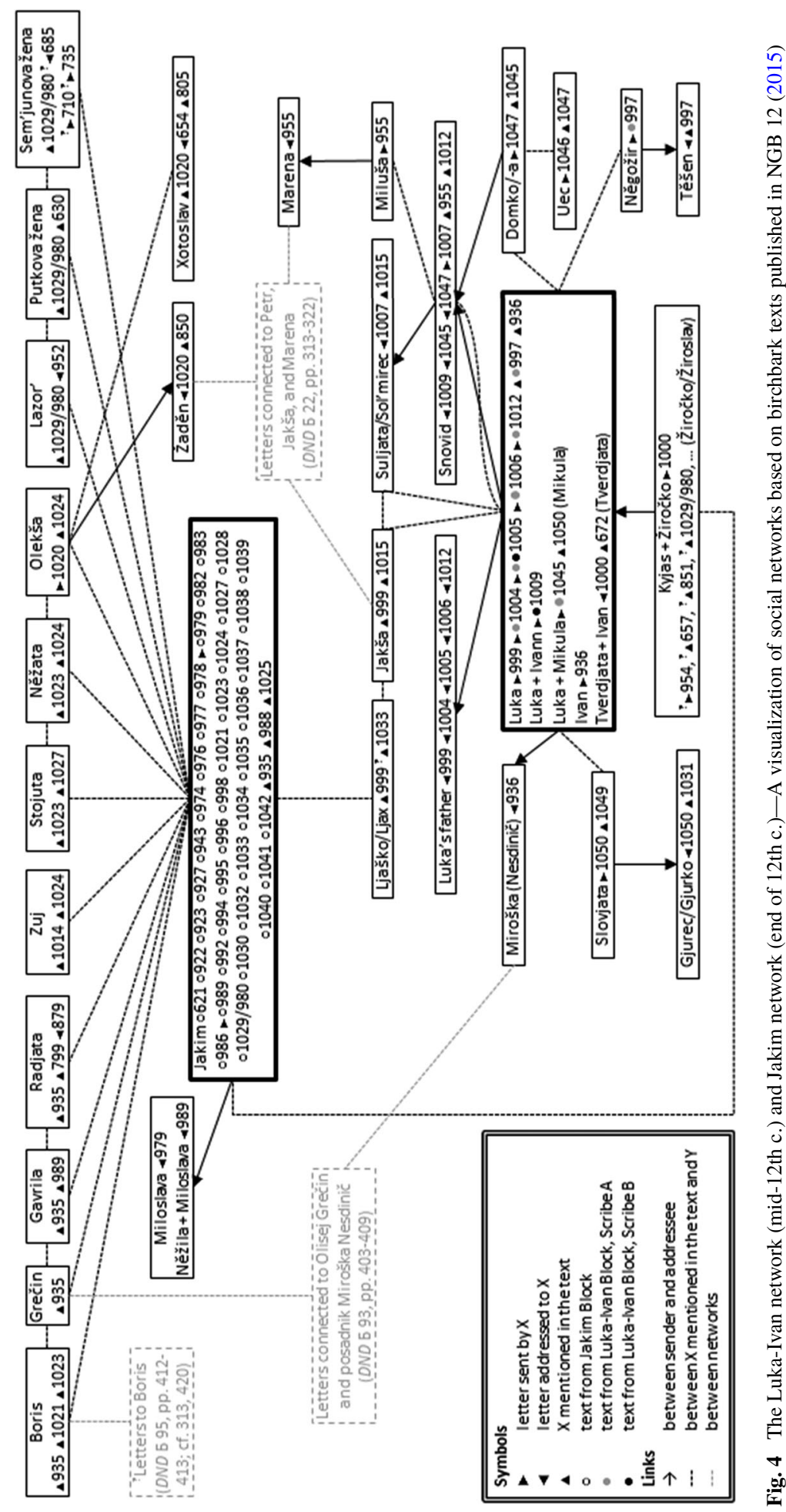


links to the names on the left and the right, i.e. to Boris, Grečin and Radjata, who are all mentioned in the same text. The diagonal dotted line from Gavrila (as well as Boris, Grečin and Radjata) to the Jakim block shows that they are all connected through N935, a list of names which includes Jakim. In addition to N935, we can see that Gavrila is mentioned in N989, which also links him to Jakim, who is now the sender and scribe $(>0)$ of a message to Něžila and Miloslava. Since Miloslava in N989 is evidently the same person as Miloslava in N979 (also written and sent by Jakim), the names are grouped together in a single node, just below Gavrila's node. ${ }^{37}$

In some cases, we find 'incomplete' relationships. For instance, N1015 appears twice (in the middle of the diagram) as a letter, which mentions Jakša and Sol'mirec as indicated by $\boldsymbol{\Lambda}$. However, N1015 cannot be found in the diagram in combination with the name of a sender or recipient due to the very fragmentary nature of the letter, which lacks the beginning of the text.

In other cases, names in birchbark texts published in NGB 12 do not appear in the diagram because no identification can be established with the same names in other birchbarks. The list of names in N935, for example, not only contains Gavrila, Boris, Grečin, Radjata and Jakim, but also other individuals like Fedor, Vasil', Sidor and Griga (mentioned above, Sect. 2.1), who are not included in the diagram. Similarly, in the upper right corner of the diagram, Lazor' is mentioned as the addressee of N952 (see above, Sect. 3); all other individuals, including the sender of the letter, Vjačeška, are left out because they are otherwise unknown in the birchbark corpus.

Finally, it should be noted that the networks presented here can be expanded if we look further beyond the texts published in NGB 12. This, for instance, is the case for Xotoslav, who not only occurs in N1020, but also in N654 (as the addressee Xotěslavko) and N805, as the diagram shows (upper right corner). As a matter of fact, Xotoslav appears in section B 79 (Letters from Ivanko associated with Ljudin End) in DND (pp. 388-389), which shows that he can be connected to a certain Ivanko (the sender of N654), who also communicated with Ortem'ja (N667). This is the Ortem'ja that we already encountered in section B 78 (Texts by Seraf'jan) in DND (pp. 385-388). From there on we can pursue other connections by means of shared names. So the Xotoslav that we mention in the diagram in relation to the Jakim block was part of a larger network of people who communicated with each other on birchbark.

\subsection{The Luka-Ivan network}

The Luka-Ivan network (see NGB 12, pp. 144-147) consists of a group of texts in which a person called Luka figures prominently next to an individual named Ivan. A considerable number has been written by two scribes:

- Scribe A (• ) is the one who wrote six documents: N997, N1004, N1005 (front side of the birchbark), N1006, N1012 and N1045. ${ }^{38}$ The name Luka occurs in three of them (N1004, N1005 and N1006) as the sender of a letter to 'father'. Since N1012, which lacks the name

\footnotetext{
${ }^{37}$ One could also draw a dotted line not only between X (Gavrila) and the sender Y (Jakim), but also the recipient of the letter from Y, i.e. between Gavrila and the addressees Něžila and Miloslava in N989. This might give even more insight into the various relationships, but at the same time it would make the diagram rather opaque with many links. Moreover, the connection between Gavrila and the recipients Něžila and Miloslava can be traced by following the dotted line between Gavrila and Jakim.

${ }^{38}$ On N997, N1004, N1005, N1006 and N1012 see above, Sect. 3.
} 
of the sender, is also addressed to 'father', it is most likely that the missing part of the incipit contained Luka's name as well. In N1045 Luka along with Mikula address Snovid. The same Mikula also seems to figure in letter N1050 ('From Slovjata a letter to Gjurec ...'), whereas Snovid is mentioned in the text in N1012 and also appears elsewhere on birchbark (see below). Furthermore, scribe A is responsible for writing N997, which contains a letter from Něgožir to Těšen on the front side of the birchbark and another message on the back in which Těšen is mentioned (indicated in the diagram by two symbols, $\boldsymbol{\varangle}$ and $\boldsymbol{\Lambda}$, under the name Těšen).

- Scribe B (• ) wrote two documents, N1005 (back side) and N1009. The latter is a letter from Luka along with Ivan to Snovid, whereas the back of N1005 seems to be the continuation of Luka's letter to his father on the front side. In N1005 scribes A and B consistently use dual forms when referring to themselves.

On the basis of this set of data, the editors of $N G B 12$ convincingly argue that Luka can be identified as scribe A and Ivan (also spelled Ivann) as scribe B. This would mean that Luka wrote N997 on behalf of Něgožir to Těšen (in which Luka mentions himself in the third person; see the combination of the symbols $\boldsymbol{\Delta}$ and $\odot$ in the diagram) and that N999another letter 'From Luka to father...'-was written by someone else on behalf of Luka. If we assume that the same Ivan also appears as the sender of N936 (a fragmentary letter addressed to Miroška which mentions the name Luka), this would also imply that N936 was not written by Ivan himself. ${ }^{39}$ In addition, Ivan can 'in principle' (“v principe”, ibid., p. 100) be identified as one of the addressees of N1000 (along with Tverdjata, who probably also figures in N672, previously published in DND, p. 386).

According to the edition (NGB 12, p. 106, 144), there is good reason to assume that Luka and Ivan were not only close business associates but also relatives, probably brothers. Luka might have been the elder, because he clearly takes the lead in N1005 when writing to his father; he also speaks for Ivan before his brother takes over the pisalo on the back of the birchbark (cf. N1009, where Ivan mentions Luka first when writing to Snovid). This conjecture is in accordance with the extrastratigraphical dating of the letters written by scribes A and B presented in the edition (ibid., pp. 144-145). In the chronological overview of the new finds (ibid., pp. 192-193) both groups of letters are assigned to the period ' $\leftarrow 1140$ ' (i.e. between 1140 and 1160, with the possibility that they could also be one interval of twenty years older).

Luka's business, which also involved his brother and other merchants, was extensive; they traded in different kinds of grain, hides and furs, horses, wine, glassware and pans. From N1009 we learn that they traded in 'Greek merchandise', i.e. imports from the Byzantine Empire or its colonies on the Black Sea, while the 'overseas merchandise', which is also mentioned in the letter, refers to products from North-Western Europe, presumably those which arrived via the Baltic sea (the default 'sea' in Old Novgorodian texts). It seems that they were on long trips away from Novgorod, while their father to whom they sent their messages and instructions was based in the city. In the preface (ibid., p. 5), the editors stress the insights gained from the new finds, which are of exceptional significance for the study of Novgorod's trade relations in the early period, as traditional written sources hardly ever show any such information.

The language found in Luka's and Ivan's letters (scribes A and B) can be characterized as a mix of dialectal (Novgorodian) and 'supra-dialectal' ("naddialektnyj”, cf. DND, p. 5)

\footnotetext{
${ }^{39}$ Interestingly, the particle že 'also' in the incipit 'From Ivan to Miroška že ...' suggests that we are dealing with a second letter to Miroška; the first letter had either been sent by Ivan to Miroška at an earlier stage, or was sent to Miroška by someone else (maybe with the same messenger) (ibid., p. 34).
} 
morphological features (see NGB 12, p. 147), which perhaps reflects the broad geographical scope of their lives and activities (outside of Novgorod). For instance, in N1012 the characteristic Novgorodian nominative singular ending in -e (samb 'self', including bytovoj spelling) is present on the back of the birchbark, whereas on the front Luka uses the more geographically widespread form in -ъ (samъ); similarly, in N997 we read prodale 'sold' versus prodalヶ in N1004.

The group of letters revolving around Luka and Ivan is not only closely related to Luka's father (the addressee of five letters by Luka) but also to Snovid. As already mentioned, Snovid figures in Luka's letter N1012; he is addressed by Luka and Ivan in N1009 and by Luka and Mikula in N1045. Among the new finds there are three other documents in which the name Snovid appears. In two of them it is clear that we are dealing with the same person (NGB 12, p. 108): in N1007 Snovid is the sender of a letter to Suljata and in N1047 he is the addressee of a letter by Domko, in which Uec is also mentioned (Uec is the author of N1046 for which the name(s) of the addressee(s) are unknown because of a lacuna in the birchbark). The names of both individuals, Suljata and Domko, are attested elsewhere in the new finds: Suljata appears in the alternative form Sol'mirec in the fragment N1015, in which we also find the name Jakša, who occurs in one of Luka's letters to his father (N999). Domko appears as Domka in Luka's and Mikula's letter to Snovid (N1045). Finally, a person called Snovid is mentioned in letter N955, in which Miluša writes to Marena about the projected marriage between Snovid and a bride called 'Big Braid' (see above, Sect. 2.3). According to the edition, we can assume ("predpoložitel'no" 'presumably', ibid., p. 56, "[v]ozmožno" 'possibly', p. 108) on the basis of the chronology and location of this extraordinary find that Snovid in N955 is the same person as in the letters mentioned above.

As argued in the edition (ibid., pp. 111-112), it might be the case that Snovid and Luka's (and Ivan's) father are actually the same person because their letters exhibit the same characteristic features. If this is true, Luka addresses his father as 'father' when writing letters by himself (N1004, N1005, N1006, N1012, and even N999, which is in a different handwriting) and as 'Snovid' when writing letters together with others (N1045, together with Mikula, and also N1009, together with his brother Ivan). There is, however, a complication if we take into account that N1012 contains both 'father' and 'Snovid': '[From Luka?] a bow to father. I am fine ...', and in the text on the back where the beginning is missing, '... to Snovid. And I myself am waiting for the grečniki merchants' ${ }^{40}$ The identification of Snovid as Luka's father would only be possible if the text on the back is not addressed to his father anymore, but to the messenger, who gets the instruction to deliver the letter to Snovid. ${ }^{41}$ This scenario, proposed by Gippius in the edition (ibid., p. 112), is certainly plausible in the light of other birchbark texts in which the messenger is explicitly addressed in the text (see above, Sect. 3).

In any case, it is clear that Luka, Ivan, their father, and - or: who was known as-Snovid, were in close contact with each other as well as other business partners about their commercial activities. Their network includes people from the upper strata of Novgorodian society: Miroška in N936 can be identified as the (future) Novgorod posadnik Miroška Nesdinič (ibid., pp. 34-35); Jakša in N999 and N1015 can be identified as the famous posadnik Jakun Miroslavič (ibid., p. 98); and Marena in N955 has plausibly been identified as the wife of the boyar Petr (or Petrok) Mixalkovič, who played a leading role in Novgorodian administration around the middle of the twelfth century (see Gippius 2004b, pp. 164-174).

\footnotetext{
${ }^{40}$ See NGB 12, pp. 112-113, for a detailed explanation of the word grečnik.

${ }^{41}$ In Fig. 4, Snovid's appearance in N1012 is indicated with the symbol $\mathbf{\Lambda}$, not claiming any specific communicative situation.
} 


\subsection{The Jakim network}

Our last observation on the Luka-Ivan network forms a bridge to another important network, which was active roughly one or two generations later. The leading character is Jakim, whose letters can be classified chronologically as ' $\leftarrow 1180$ ' (i.e. between 1180 and 1200, with the possibility that they could also be one interval of twenty years older; see NGB 12, pp. 192193 and also p. 137: stratigraphical dating between the sixties and the mid-nineties of the twelfth century). We can reliably connect the prominent Novgorodian citizens Jakša, Marena and Miroška, featured in the Luka-Ivan network, to Jakim and his social entourage:

- Jakša (Jakun Miroslavič) and Marena belong to a group of texts dealt with under section Б 22 in DND (pp. 313-322; see also pp. 401-402: Texts associated with Petr (Petrok), Jakša and Marena (probably between the thirties and seventies of the twelfth century). In this network an individual named Žaděn appears in N850, which can be dated rather precisely (1148 or a bit later). N850 is a letter 'from Borz, Put'ša and all companions to Petrok'. On the outer side of the birchbark a person called Žaděn is mentioned ('and give Žaděn ...'). Apparently, the same Žaděn shows up in N1020 where he is the addressee of a letter from Olekša (NGB 12, p. 117). ${ }^{42}$ Olekša himself occurs in N1024, a fragmentary text written by Jakim. ${ }^{43}$

- Miroška (Nesdinič) figures in a slightly younger group of texts classified under section B 93 in DND (pp. 403-409): Texts associated with Olisej Grečin and posadnik Miroška Nezdinič $^{44}$ (probably between the seventies and nineties of the twelfth century). He is the sender (who goes by the name of Mir[o]slav) of a letter (N502) to the well-known priest and icon-painter Olisej Grečin (see above, Sect. 2.4), and the addressee, along with the same Grečin, of a letter from Smolig (N603). In the diagram, we see that the name Grečin appears in N935, a list of names (of debtors or investors), in which also a certain Jakim is mentioned. According to NGB 12 (p. 33), Jakim can be identified as the letter writer under discussion ("[s] vysokoj verojatnost'ju” 'to a high degree of probability') and Grečin is our Olisej Grečin ("praktičeski nadežno" 'practically certainly'). ${ }^{45}$

In addition, it might also be possible, though to a lesser degree, to link the Luka-Ivan and Jakim networks through N1033 and N1029/980. In N1033, one of Jakim's letters, we find a person called Ljax; he might be identified ("v principe" 'in principle', ibid., p. 133) as Ljaško, who together with Jakša appears in one of Luka's letters to his father (N999). The relationship between the two networks in the case of one of Jakim's administrative documents,

\footnotetext{
${ }^{42}$ As for N1020, which was already mentioned above (Sect. 4.1), the editors point out (ibid., p. 131) that a hypocoristic derivation of the name Xotoslav, who appears in N1020, can be found in N1031 in the form of Xotura. N1031 is a letter from Něžko to Budko, in which the sender not only mentions Xotura but also Gjurko. This Gjurko also seems to appear as Gjurec in N1050, which connects N1031 to Slovjata, Mikula and Luka (see the nodes in the diagram to the left of the center of the Luka-Ivan network). The editors not only discuss the linguistic relationship between the names Xotoslav in N1020 and Xotura in N1031, but also speculate on the identification of the two individuals, who might be the same person (ibid.). Chronologically there is nothing against such an identification because both texts are assigned to the interval '1160 $\rightarrow$ ' (ibid., p. 193). Although the connection of N1020 and N1031 through Xotoslav / Xotura remains speculative, this would imply a rather direct link between the Luka-Ivan and Jakim networks.

${ }^{43}$ It is not very clear why the editors of NGB 12 do not relate Olekša in N1020 and N1024 with the possessive Olekšino 'Olekša's' in N976, which together with N1024 belongs to the Jakim block.

${ }^{44}$ Note the variation in spelling of the normalized version of the name (a derivation of Nesъda; see DND, p. 357): in $D N D$ it is usually 'Nezdinič' and in NGB 12 'Nesdinič'.

${ }^{45}$ Incidentally, it has been assumed that Olisej Grečin (Petrovič) was the son of Petr / Petrok Mixalkovič (DND, p. 403; Gippius 2005b).
} 
N1029/980, in which the name Žiroslav is listed, is even less certain. One of the possible candidates in the birchbark corpus who might be identified as Žiroslav is the hypocoristic Žiročko, who along with Kyjas wrote letter N1000 to Tverdjata and Ivan, i.e. Luka's business partner and perhaps brother. However, there are also other candidates for a possible identification as Žiroslav in N1029/980 (e.g., Žiročka in N851, Žiročko in N954, or Žiroslav in N657; see ibid., p. 54, 99, 127).

As for Jakim's writing activities, we are dealing with by far the largest block on birchbark (see ibid., pp. 137-141). The diagram shows no less than 37 documents written by Jakim, who turned out to be the most productive writer in Novgorod (ibid., p. 5). Three texts were unearthed in 2002, one in 2003, fourteen in 2010 and eighteen in 2012, ${ }^{46}$ to which one extra fragment by the same hand can be added, N621, which has already been found by 1984 (published in NGB 9, pp. 24-25; DND, p. 454). Jakim identifies himself only in two instances, namely as the sender of N979 ('From Jakim to Miloslava ...') and N989 ('From Jakim to Něžila and to Miloslava ...'). Except for these two fragmentary letters, his legacy on birchbark mainly consists of notes, which reveal a wide range of activities dealing with church practice as well as household management (perhaps at the same time or in different stages of his life as speculated in NGB 12, p. 140). No doubt Jakim was a trained and well-educated scribe who could skillfully draw up an outline of a troparion (N977), took care of parchment supplies (N992: ' $\ldots$. and I from the priest in Gorodišče [?] . . . and for 5 ells of red cloth a grivna ... and for parchment [a grivna?] ...') and other monastic goods like oil (maslo, N995) and headgear (klobukz, N982). Other documents show Jakim in his role as manager of a large boyar household where he dealt with the exchange of all kinds of commodities (for instance oat, beans, peas, barley, linseed, rye and salt in N1023) and handled the financial administration, which included handling substantial sums of money as is the case in N1021, which speaks of a transaction of approx. 3,100 squirrel-furs for the amount of 2,233 $\mathrm{ku}$ nas (i.e. approx. 89 grivnas). From other letters in which Jakim is mentioned (N935, N988, N1025) we learn that he acted as the collector of messages (N988: '.. give the [birchbark] letter to Jakim yourself ...') and as a messenger himself (N1025: '.. and mother knows, and this Jakim ...', where the pronoun 'this' clearly points to the person who delivered the letter; see above, Sect. 3).

Jakim was certainly not the author (beneficiary) of all documents he wrote; in several instances he merely acted as a scribe on the behalf of others, as is the case in N983, which apparently deals with the preparations for some sort of communal feast, or in the case of the above-mentioned document N1021, where the huge amount of money was paid by two people: the unidentified author, on whose behalf Jakim wrote the note, and a person called Boris ('... And Boris paid forty-four grivnas and five and a half kunas ...'). It has been suggested by Gippius (ibid., p. 119) that the author and Boris may have been brothers and that Jakim worked for the oldest of the two, i.e. the author of N1021. ${ }^{47}$ It seems that Jakim also refers to the two brothers in N1023, where it says: '... If he takes more, then it regards both, if he takes less, [also] both ...' ('both' clearly denotes the same estate owners (apparently brothers) who play a role in no. 1021, ibid., p. 122). In the diagram a tentative link has been established between Boris in N1021 and N1023 (as well as in N935 where Boris together

\footnotetext{
${ }^{46}$ Note that the information on the excavation years given on p. 5 of NGB 12 is at odds with the exact data on p. 17.

${ }^{47}$ According to a hypothesis voiced in 2012 (see http://mitrius.livejournal.com/913355.html and http://mitrius. livejournal.com/913766.html), the unidentified author of N1021 might have been Dmitr, the older brother of Boris; both were sons of Miroška Nesdinič (see above). Dmitr would be identical to the hypocoristic name Domko / -a in birchbark letters N1045 and N1047, which are part of the Luka-Ivan network (see above, Sect. 4.2). This hypothesis proved to be untenable due to chronological incompatibilities.
} 
with Jakim and others are mentioned in a list of names) and a group of texts treated under section B 95 in DND (pp. 412-413): Letters to Boris (between the seventies and nineties of the twelfth century). The editors of NGB 12 (pp. 33-34) mention the possibility that we are dealing with the same person, although the degree of plausibility is rather low. For this reason, the link in the diagram is accompanied by a question mark.

As for the rest of the network in which Jakim's written activities can be situated, there are some other instances in which the new finds can be linked to documents that have been published in previous volumes of $N G B$. Among the individuals listed in N935 there is the name Radjata, which also appears in N799 and N879 (see section B 57, texts associated with Radjata, in DND, pp. 368-369). In N879 Radjata is the addressee of a letter from Žirjata, one of the candidates who might be identified as the hypocoristic Žiročko in N954 and N1000, Žiroslav in N1029/980, and other alternatives (see above). N1020, a letter from Olekša to Žaděn, has already been mentioned above and the same holds for Xotoslav who appears in the same text (see also Sect. 4.1 above). Finally, N1029/980 includes the names 'Putka's wife' and 'Sem'jun's wife'. The first name also occurs in N630, which is an administrative list, where the name Žirko (On'kovič) is also recorded. According to NGB 12, p. 54, this Žirko is, again, one of the candidates who might be the same person as Žiročko in N954 and other birchbark documents. 'Sem'jun's wife' in N1029/980 might be connected to the name of her husband, Sem'jun, who occurs in N685, N710 and N735: Although there is not enough evidence to identify all these characters, it still seems certain that there are not four different Sem'juns connected to this name (ibid., p. 127).

As already mentioned above, Jakim's oeuvre on birchbark can be positioned chronologically between the sixties and mid-nineties of the twelfth century. Interestingly, Jakim appears to be sensitive to some linguistic innovations which are otherwise common to historical documents from the beginning of the thirteenth century. Most prominently, he already 'dropped his jers' in a period that is labelled 'Early Old Russian' (until approx. 1220), in distinction to the subsequent 'Late Old Russian' phase, which is characterized by the fall of the jers. Obviously, in certain idiolects this innovation took place earlier than was expected on the basis of previous evidence (ibid., p. 137, see pp. 140-141 for details).

\subsection{Other identifications}

Besides the two large networks discussed above, the new data in NGB 12 include some other identifications of shared names. To begin with, it is probable that Bratila, the addressee of N934, is the same person as Bratila, the sender of N803. The sender of N934, Domaška, may be identified as Domačko in N657 and Domaško in N926. Gjulopinič, who also appears in N926, might well be the son of Gjulopa in N729. All these relationships, which are pointed out in NGB 12 (pp. 19-20, 31-32), were already included in DND, section B 94 (pp. 409412): texts associated with Bratila and Domaška (probably between the last quarter of the twelfth and the beginning of the thirteenth century).

Furthermore, the following incidental identifications can be established: Samson Ivanov (Ivanovič), whose name is mentioned in the official document N932 from the early fifteenth century, appears to be the grandson of posadnik Vasilij Ignat'evič to whom letter N135 is addressed; both were descendants of the prominent Mišiniči boyar clan (DND, p. 511, 627, 676-677; NGB 12, pp. 28-29). Semka, the recipient of Něžila's letter N1026 (see above, Sect. 3), ${ }^{48}$ seems to be identical to the Semka who is mentioned in N1001 (NGB 12, pp. 100101, 125-126). Finally, the individuals Rat'ša, Jerem'ja and Sofontij figure more than once

\footnotetext{
${ }^{48}$ The editors of NGB 12 do not relate Něžila in N1026 to Něžila in N989 (see Sects. 4.1 and 4.3 above). Apparently, an identification is not realistic for chronological reasons.
} 
in the birchbark corpus: Rat'ša in N993 (second half of the twelfth century) might be the individual with the same name who is mentioned in N665 (ibid., p. 94); Jerem'ja is the addressee of two letters from the second half of the fourteenth century, N948 and N949 (ibid., pp. 42-44); and Sofontij in N962, a rather recent letter from around 1430-1450, could well be identified with the same name in N466 (ibid., pp. 69-73).

The nine new texts from NGB 12 discussed in this subsection, together with the 62 new texts presented in Fig. 4, show that almost 50\% of the 146 texts found in Novgorod between 2001 and 2014 are interconnected in terms of shared names on birchbark and participation in social networks. The percentage is even substantially higher-over $70 \%$-if we only take into account the texts that reveal personal names and/or belong to a block for which the writer is known (approx. 100 out of 146).

In the total number of 146 texts we can count about 150 different personal names (see the index of NGB 12, pp. 177-191); ${ }^{49}$ some 95 of these individuals, i.e. two-thirds, figure in the networks discussed above. As we have seen, the new texts include names that are also known from other historical sources, most notably the Novgorod posadniks Miroška Nesdinič and Jakun Miroslavič. All these insights stress the importance of a more refined analysis (including visualizations) of social networks on birchbark as advocated in the beginning of Sect. 4.

\section{Concluding remarks}

The landmark N1000, which was cited at the beginning of this paper, has been the subject of our investigations in several of the previous sections; we have discussed the provenance of the name Kyas and corroborating epigraphic evidence (Sect. 2.4), and Tverdjata, Ivan and especially Žiročko have been positioned within the extensive Luka-Ivan network (Sect. 4.2). Throughout this study, many other birchbark texts have been dealt with on several occasions. Take for instance, N935, which just like N1000 may appear at first sight to be a simple note, is in this case an administrative list with some dozen names. In fact, in the course of our review, the document turned out to contain new historical information (see Griga in Sect. 2.1), be connected to recent epigraphic research (see Olisej Grečin in Sect. 2.4), and directly linked to the prominent Jakim block (Sect. 4.3).

N935 and N1000 are only two examples of the first batch of birchbark finds from the twenty-first century. In general, I hope to have shown that the twelfth volume of $N G B$ has brought to light a wealth of new information and insights into a variety of dimensionslinguistic, philological and historical. NGB 12 splendidly illustrates the dynamics of berestology—undoubtedly, the most dynamic research field in Slavic historical linguistics.

\footnotetext{
${ }^{49}$ The exact number of personal names cannot be determined because of some unclear instances like the incomplete form zu in N1014 (Zuja? zuba?, see NGB 12, p. 114) or the form Lěšanz in N1050 (nickname? inhabitants of a village?, ibid., p. 151). Needless to say, different individuals with the same name have been counted separately (e.g., Luka in N1054 from the second half of the thirteenth century-see above, Sect. 3-is certainly not our Luka from the Luka-Ivan network). Excluded are personal names which appear exclusively in texts from Staraja Russa (e.g., Grigor' ja, Jermola and Ozěkěi in no. 39); which are part of standard expressions (e.g., Petrovъ denь 'St. Peter's Day' in N962, Rozvaža ulica 'Rozvad's Street' in N1055); which can be found in texts discovered before 2001 (i.e. N960 and N961); and, of course, which occur in Church Slavonic documents (e.g., Jesif and Marija in N916). Included are personal names which appear as nick-names (e.g., Nozdr'ka 'Nostril' in N954, Kosa Velikaja 'Big Braid' in N955); in the form of possessive adjectives (e.g., Tëxonь konь 'Těxon's horse' in N926, (D)anilovo l(ukъšbko) 'Danilo's basket' in N1056); or as patronymic only (e.g., Gjulopinič in N926).
} 
Open Access This article is distributed under the terms of the Creative Commons Attribution 4.0 International License (http://creativecommons.org/licenses/by/4.0/), which permits unrestricted use, distribution, and reproduction in any medium, provided you give appropriate credit to the original author(s) and the source, provide a link to the Creative Commons license, and indicate if changes were made.

\section{References}

Artamonov, Ju. A., \& Gippius, A. A. (2012). Drevnerusskie nadpisi Sofii Konstantinopol'skoj. In K. V. Nikoforov (Ed.), Slavjanskij al'manax 2011 (pp. 41-52). Moskva.

Artamonov, Ju. A., Gippius, A. A., \& Zajcev, I. V. (2009). Iz drevnerusskoj épigrafiki Konstantinopol'skoj Sofii. Ruthenica, 8, 227-243.

Artamonov, Ju. A., Gippius, A. A., \& Zajcev, I. V. (2010). Russkie palomniki “U svjatyx strastej” (Iz èpigrafiki sv. Sofii v Konstantinopole-Stambule). In E. A. Mel'nikova (Ed.), Vostočnaja Evropa v drevnosti $i$ srednevekov'e. Ustnaja tradicija v pis'mennom tekste. XXII čtenija pamjati člena-korrespondenta AN SSSR Vladimira Terent'eviča Pašuto. Moskva, 14-16 aprelja 2010 g. Materialy konferencii (pp. 14-21). Moskva.

Artamonov, Ju. A., Gippius, A. A., \& Zajcev, I. V. (2012). Drevnerusskie nadpisi-graffiti Konstantinopol'skoj Sofii. Predvaritel'nye itogi issledovanija. In A. Derevjanko, A. Kudelin, \& V. Tiškov (Eds.), 1150 let Rossijskoj gosudarstvennosti i kul'tury. Materialy k Obščemu sobraniju Rossijskoj akademii nauk, posvjaščennomu Godu rossijskoj istorii (Moskva, 18 dekabrja 2012 g.) (pp. 282-292). Moskva.

Artamonov, Ju. A., Gippius, A. A., \& Zajcev, I. V. (2013). "I s otcom, i s mater'ju, i so vseju brat'eju ...": Dva drevnerusskix graffito iz baziliki Roždestva Xristova v Vifleeme. Drevnjaja Rus'. Voprosy medievistiki, 2(52), 86-91.

Artamonov, Ju. A., Gippius, A. A., \& Zajcev, I. V. (2016). Vostočnoslavjanskie nadpisi baziliki Roždestva Xristova v Vifleeme. Rossijskaja arxeologija, 2016(1), 25-36.

Bobrik, M. A. (2008). Novye svedenija o berestjanoj gramote 916. Russkij jazyk v naučnom osveščenii, 16(2), 246-256.

Brun, A.-S., Hartmann-Virnich, A., Ingrand-Varenne, E., \& Mikheev, S. M. (2014). Old Russian Graffito Inscription in the Abbey of Saint-Gilles, South of France. Slověne. International Journal of Slavic Studies, $3(2), 110-129$.

Collins, D. E. (2011). Reconstructing the pragmatics of a medieval marriage negotiation (Novgorod 955). Russian Linguistics, 35(1), 33-61. doi:10.1007/s11185-010-9070-7.

Dekker, S. (2016). Old Russian birchbark letters: a pragmatic approach (Doctoral dissertation). Leiden University, Leiden.

DND: Zaliznjak, A. A. (2004a). Drevnenovgorodskij dialekt. Vtoroe izdanie, pererabotannoe s učetom materiala naxodok 1995-2003 gg. Moskva.

Franklin, S. (2002). Writing society and culture in Early Rus, c. 950-1300. Cambridge.

Gippius, A. A. (2004a). K pragmatike i kommunikativnoj organizacii berestjanyx gramot. In NGB 11 (pp. 183-232).

Gippius, A. A. (2004b). O neskol'kix personažax novgorodskix berestjanyx gramot XII veka. In NGB 11 (pp. $164-182)$.

Gippius, A. A. (2005a). "Sisinieva legenda" v novgorodskoj berestjanoj gramote. In L. G. Nevskaja, T. N. Svešnikova, \& V. N. Toporov (Eds.), Zagovornyj tekst. Genezis i struktura (pp. 136-142). Moskva.

Gippius, A. A. (2005b). K biografii Oliseja Grečina. In O. E. Ėtingof (Ed.), Cerkov' Spasa na Neredice: ot Vizantii k Rusi. K 800-letiju pamjatnika (pp. 99-114). Moskva.

Gippius, A. A. (2009). Berestjanoe "xitrospletenie" XII v. (gramota No 88). In N. A. Makarov (Ed.), Velikij Novgorod i Srednevekovaja Rus'. Sbornik statej: k 80-letiju akademika V. L. Janina (pp. 37-43). Moskva.

Gippius, A. A. (2012). "Il'djatino selišče": kommentarij k novgorodskoj berestjanoj gramote No. 71. In Ju. Ė. Šustova (Ed.), Problemy diplomatiki, kodikologii i aktovoj arxeografii. Materialy XXIV Meždunarodnoj naučnoj konferencii. Moskva, 2-3 fevralja 2012 g. (pp. 231-234). Moskva.

Gippius, A. A. (2015). Ešče raz o novgorodskoj berestjanoj gramote No. 724. Slověne. International Journal of Slavic Studies, 4(1), 111-127 [K 70-letiju prof. M. V. Roždestvenskoj i prof. T. V. Roždestvenskoj].

Gippius, A. A., \& Mixeev, S. M. (2011). Zametki o nadpisjax-graffiti novgorodskogo Sofijskogo sobora. Č. III. Drevnjaja Rus'. Voprosy medievistiki, 2(44), 37-57.

Gippius, A. A., \& Mixeev, S. M. (2013a). Nadpisi-graffiti smolenskogo Sobora na Protoke iz fondov Novgorodskogo muzeja. Voprosy epigrafiki, 7(2), 175-183.

Gippius, A. A., \& Mixeev, S. M. (2013b). O podgotovke Svoda nadpisej-graffiti Novgorodskogo Sofijskogo sobora. In A. A. Pičxadze, L. I. Sazonova, \& A. L. Toprokov (Eds.), Pis'mennost', literatura, fol'klor slavjanskix narodov. Istorija slavistiki. XV Meždunarodnyj s"ezd slavistov. Minsk, 20-27 avgusta 2013 g. Doklady Rossijskoj delegacii (pp. 152-179). Moskva. 
Gippius, A. A., \& Schaeken, J. (2011). On direct speech and referential perspective in birchbark letters no. 5 from Tver' and no. 286 from Novgorod. Russian Linguistics, 35(1), 13-32. doi: $10.1007 / \mathrm{s} 11185-010-9069-0$.

Gippius, A. A., \& Zaliznjak, A. A. (2016). Berestjanye gramoty iz novgorodskix raskopok 2015 g. Voprosy jazykoznanija, 4, 7-17.

Gippius, A. A., Zaliznjak, A. A., \& Koval', V. Ju. (2011). Berestjanaja gramota iz raskopok v Moskovskom Kremle. In S. A. Beljaev et al. (Eds.), Moskovskij Kreml' XV stoletija. Tom 1: Drevnie svjatyni $i$ istoričeskie pamjatniki (pp. 452-455). Moskva.

Gippius, A. A., Gzella, H., Mikheev, S. M., \& Schaeken, J. (2012). The oldest traces of Semitic (Hebrew and Syriac) in early Rus': two inscriptions in the St. Sophia Cathedral in Novgorod. Russian Linguistics, 36(3), 271-284. doi:10.1007/s11185-012-9099-x.

Gippius, A. A., Zaliznjak, A. A., \& Toropova, E. V. (2017). Berestjanye gramoty iz raskopok 2016 g. v Velikom Novgorode i Staroj Russe. Voprosy jazykoznanija, 2017 (forthcoming).

Gordin, A. M., \& Roždestvenskaja, T. V. (2016). "Idja ko svjatomu Iakovu”: drevnerusskoe graffito XII v. v Akvitanii. Slověne. International Journal of Slavic Studies, 5(1), 126-147.

Janin, V. L. (1991). Novgorodskie akty XII-XV vv. Xronologičeskij kommentarij. Moskva.

Janin, V. L. (1998). Ja poslal tebe berestu... (3rd ed.). Moskva.

Malygin, P. D. (2011). Berestjanye gramoty drevnego Toržka (iz raskopok 1985 i 1999-2001 gg.). Tver'.

Mixeev, S. M. (2010). Zametki o nadpisjax-graffiti novgorodskogo Sofijskogo sobora. Čast' I. Drevnjaja Rus'. Voprosy medievistiki, 2(40), 91-102.

Mixeev, S. M. (2012). 22 drevnerusskix glagoličeskix nadpisi-graffiti XI-XII vekov iz Novgoroda. Slovo, 62, 63-99.

NGB 7: Arcixovskij, A. V., \& Janin, V. L. (1978). Novgorodskie gramoty na bereste. Iz raskopok 1962-1976 gg. Moskva.

NGB 9: Janin, V. L., \& Zaliznjak, A. A. (1993). Novgorodskie gramoty na bereste. Iz raskopok 1984-1989 gg. Moskva.

NGB 10: Janin, V. L., \& Zaliznjak, A. A. (2000). Novgorodskie gramoty na bereste. Iz raskopok 1990-1996 gg. Paleografija berestjanyx gramot i ix vnestratigrafičeskoe datirovanie. Moskva.

NGB 11: Janin, V. L., Zaliznjak, A. A., \& Gippius, A. A. (2004). Novgorodskie gramoty na bereste. Iz raskopok 1997-2000 gg. Moskva.

NGB 12: Janin, V. L., Zaliznjak, A. A., \& Gippius, A. A. (2015). Novgorodskie gramoty na bereste. Iz raskopok 2001-2014 gg. Moskva.

Petruxin, P. V. (2009). K izučeniju novgorodskoj berestjanoj gramoty No. 724. Russkij jazyk v naučnom osveščenii, 17(1), 109-126.

Rybina, E. A. (1998). Risunki srednevekovyx novgorodcev (po arxeologičeskim materialam). In T. A. Puškina (Ed.), Istoričeskaja arxeologija. Tradicii i perspektivy. K 80-letiju so dnja roždenija Daniila Antonoviča Avdusina (pp. 15-27). Moskva.

Schaeken, J. (2011). Don't shoot the messenger. A pragmaphilological approach to birchbark letter no. 497 from Novgorod. Russian Linguistics, 35(1), 1-11. doi:10.1007/s11185-010-9068-1.

Schaeken, J. (2012a). The birchbark documents in time and space-revisited. In K. Zilmer \& J. Jesch (Eds.), Epigraphic literacy and christian identity. Modes of written discourse in the newly christian European north (Utrecht Studies in Medieval Literacy, 4, pp. 201-224). Turnhout.

Schaeken, J. (2012b). Stemmen op berkenbast. Berichten uit middeleeuws Rusland: dagelijks leven en communicatie. Leiden.

Schaeken, J. (2014). Don't shoot the messenger: Part two. Pragmaphilological notes on birchbark letters nos. 497 and 771 from Novgorod and no. 2 from Zvenyhorod. In E. Fortuin et al. (Eds.), Dutch Contributions to the Fifteenth International Congress of Slavists, Minsk: Linguistics (Studies in Slavic and General Linguistics, 40, pp. 155-166). Amsterdam, New York.

Schaeken, J., Fortuin, E., \& Dekker, S. (2014). Sxaken, J., Fortejn, Ė., \& Dekker, S. (2014). Ėpistoljarnyj dejksis v novgorodskix berestjanyx gramotax. Voprosy jazykoznanija, 1, 21-38.

Temčin, S. Ju. (2015). Sirijskaja fraza “parexъ mari” v graffito XI v. novgorodskoj Sofii i cerkovnoslavjanskij perevod Ieronimova Žitija Ilariona Velikogo. In E. A. Mel'nikova (Ed.), Vostočnaja Evropa v drevnosti i srednevekov'e. Gosudarstvennaja territorija kak faktor politogeneza. XXVII čtenija pamjati členakorrespondenta AN SSSR Vladimira Terent'eviča Pašuto. Moskva, 15-17 aprelja 2015 g.: Materialy konferencii (pp. 259-264). Moskva.

Valk, S. N. (Ed.) (1949). Gramoty Velikogo Novgoroda i Pskova. Moskva, Leningrad.

Vermeer, W. (1995). Towards a thousand birchbark letters. [Review of: V. L. Janin, A. A. Zalizjnak: Novgorodskie gramoty na bereste (iz raskopok 1984-1989 gg.), Moskva: Nauka, 1993, 348 str.]. Russian Linguistics, 19(1), 109-123.

Zaliznjak, A. A. (2000). Paleografija berestjanyx gramot i ix vnestratigrafičeskoe datirovanie. In NGB 10 (pp. 133-429). 
Zaliznjak, A. A. (2002). Drevnerusskaja grafika so smešeniem ъ-o i ъ-e. In A. A. Zaliznjak (Ed.), Russkoe imennoe slovoizmenenie. S priloženiem izbrannyx rabot po sovremennomu russkomu jazyku i obščemu jazykoznaniju (pp. 577-612). Moskva.

Zaliznjak, A. A. (2004a). See above: DND.

Zaliznjak, A. A. (2004b). K izučeniju drevnerusskix nadpisej. In NGB 11 (pp. 233-287). 